\title{
Endogenous Serotonin Excites Striatal Cholinergic Interneurons via the Activation of 5-HT 2C, 5-HT6, and 5-HT7 Serotonin Receptors: Implications for Extrapyramidal Side Effects of Serotonin Reuptake Inhibitors
}

\author{
Paola Bonsi', Dario Cuomo ${ }^{1,2}$, Jun Ding ${ }^{3}$, Giuseppe Sciamanna', Sasha Ulrich ${ }^{3}$, Anne Tscherter ${ }^{2}$, \\ Giorgio Bernardi ${ }^{1,2}$, D James Surmeier ${ }^{3}$ and Antonio Pisani*,1,2 \\ IFondazione Santa Lucia I.R.C.C.S., European Brain Research Institute, Rome, Italy; ${ }^{2}$ Clinica Neurologica, Dipartimento di Neuroscienze, \\ Università di Roma 'Tor Vergata', Rome, Italy; ${ }^{3}$ Department of Physiology, Feinberg School of Medicine, Northwestern University, Chicago, IL, USA
}

\begin{abstract}
The striatum is richly innervated by serotonergic afferents from the raphe nucleus. We explored the effects of this input on striatal cholinergic interneurons from rat brain slices, by means of both conventional intracellular and whole-cell patch-clamp recordings. Bathapplied serotonin (5-HT, 3-300 $\mu \mathrm{M})$, induced a dose-dependent membrane depolarization and increased the rate of spiking. This effect was mimicked by the 5-HT reuptake blockers citalopram and fluvoxamine. In voltage-clamped neurons, 5-HT induced an inward current, whose reversal potential was close to the $\mathrm{K}^{+}$equilibrium potential. Accordingly, the involvement of $\mathrm{K}^{+}$channels was confirmed either by increasing extracellular $\mathrm{K}^{+}$concentration and by blockade of $\mathrm{K}^{+}$channels with barium. Single-cell reverse transcriptase-polymerase chain reaction (RT-PCR) profiling demonstrated the presence of 5-HT2C, 5-HT6, and 5-HT7 receptor mRNAs in identified cholinergic interneurons. The depolarization/inward current induced by 5-HT was partially mimicked by the 5-HT2 receptor agonist 2,5-dimethoxy4-iodoamphetamine and antagonized by both ketanserin and the selective 5-HT2 C antagonist RSI0222I, whereas the selective 5-HT3 and 5-HT4 receptor antagonists tropisetron and RS23597-190 had no effect. The depolarizing response to 5-HT was also reduced by the selective 5-HT6 and 5-HT7 receptor antagonists SB258585 and SB269970, respectively, and mimicked by the 5-HT7 agonist, 5-CT. Accordingly, activation of either 5-HT6 or 5-HT7 receptor induced an inward current. The 5-HT response was attenuated by $U 73122$, blocker of phospholipase C, and by SQ22,536, an inhibitor of adenylyl cyclase. These results suggest that 5-HT released by serotonergic fibers originating in the raphe nuclei has a potent excitatory effect on striatal cholinergic interneurons.

Neuropsychopharmacology (2007) 32, 1840- 1854; doi:I 0. I038/sj.npp. I 30 I294; published online 3 January 2007
\end{abstract}

Keywords: striatum; slices; 5-HT; TANs; electrophysiology; cholinergic interneuron

\section{INTRODUCTION}

Striatal cholinergic signaling is considered to play a central role in motor control as well as in the pathophysiology of different movement disorders such as Parkinson's disease, Huntington's chorea, dystonia, and most recently in progressive supranuclear palsy (Lehmann and Langer, 1983; Albin et al, 2003; Saulle et al, 2004; Warren et al, 2005). Cholinergic interneurons account for a small proportion of the entire striatal neuronal population. In spite of this, the striatum is one of the brain areas with the

*Correspondence: Dr A Pisani, Clinica Neurologica, Dipartimento di Neuroscienze, Università di Roma 'Tor Vergata', Via Montpellier I, Rome 00133, Italy, Tel: + 390672596010 , Fax: + 390672596006 , E-mail: pisani@uniroma2.it

Received 12 January 2006; revised 3 October 2006; accepted 2 November 2006 highest acetylcholine content (Izzo and Bolam, 1988). Cholinergic interneurons receive glutamatergic afferents predominantly from the centromedian and parafascicular thalamic nuclei, and to a lesser extent from the cortex. They are also recipient of a crucial dopaminergic innervation from the substantia nigra pars compacta, and of GABAergic afferents from striatal interneurons. Each of these transmitters has been shown to profoundly modulate both the intrinsic excitability and the synaptic efficacy and plasticity of these interneurons (Yan et al, 1997; Yan and Surmeier, 1997; Aosaki et al, 1998; Suzuki et al, 2001; Pisani et al, 2000; Bonsi et al, 2004, 2005; Maurice et al, 2004).

The basal ganglia in primates receive a significant serotonergic input from the anterior raphe nuclei, although the densities and patterns of innervation vary (Lavoie and Parent, 1990). The ventral striatum is particularly enriched in serotonergic terminals, that are also substantial in the dorsal striatum. Growing evidence indicates that the striatal 
serotonergic innervation contributes to motor function. In Parkinson's disease, striatal levels of 5-HT fall in parallel with those of dopamine, potentially contributing to motor and affective symptoms (Halliday et al, 1990; Sandyk and Fisher, 1988). Moreover, selective 5-HT reuptake inhibitors, widely used to treat depression, have been reported to induce a variety of movement disorder, including tremor, parkinsonism, and dystonia (Leo, 1996; Caley, 1997).

In spite of its clinical importance, little attention has been paid in understanding how 5-HT regulates the activity of identified striatal cell types, like the cholinergic interneuron (cf. Park et al, 1982; Yakel et al, 1988; Stefani et al, 1990). Our study was designed to analyze the effects of 5-HT on intrinsic membrane properties of cholinergic interneurons and to unravel the receptor subtypes and ionic mechanisms involved. To accomplish this, we utilized a combination of pharmacological, electrophysiological, and molecular approaches. Our results suggest that 5-HT activates 5-HT2C, 5-HT6, and 5-HT7 receptors, leading to increased excitability of cholinergic interneurons mainly by acting on $\mathrm{K}^{+}$ currents. This modulatory activity is likely contributing to shape interneuron excitability and influence the overall striatal output.

\section{METHODS}

\section{Tissue Preparation}

The animal experimental protocols performed in this study were in accordance to the guidelines of the European Union Council (86/609/EU) and to the Animal Act (1986). All efforts were made to minimize animal suffering and the number of animals utilized. Male Wistar rats, 3-4 weeks old, were anesthetized and killed by cervical dislocation. After rapid removal of the brain from the skull, corticostriatal coronal slices $(180-200 \mu \mathrm{m})$ were prepared from tissue blocks with the use of a vibratome in oxygenated Krebs' solution (see composition below) (Pisani et al, 2000; Bonsi et al, 2004, 2005). After 30-60 min recovery, a single slice was transferred into a recording chamber (0.5-1 ml volume) mounted on the stage of an upright microscope (BX51WI, Olympus, Milan, Italy) equipped with a $20 \times, 0.95$ n.a. water immersion objective (XLUMPlan Fl, Olympus), and submerged in a continuously flowing $(2-3 \mathrm{ml} / \mathrm{min})$ solution at $32-33^{\circ} \mathrm{C}$ gassed with $95 \% \mathrm{O}_{2} / 5 \% \mathrm{CO}_{2}$. At this flow rate, chemicals reached the chamber within $30-50 \mathrm{~s}$. The composition of the solution was (in $\mathrm{mM}$ ): $126 \mathrm{NaCl}, 2.5$ $\mathrm{KCl}, 1.3 \mathrm{MgCl}_{2}, 1.2 \mathrm{NaH}_{2} \mathrm{PO}_{4}, 2.4 \mathrm{CaCl}_{2}, 10$ glucose, 18 $\mathrm{NaHCO}_{3}$.

\section{DIC Infrared Videomicroscopy}

Individual interneurons were visualized in situ using a differential interference contrast (DIC, Nomarski) optical system combined with an infrared (IR) filter and a monochrome CCD camera (C6790, Hamamatsu, Japan). Cholinergic interneurons were impaled under visual guidance, according to their peculiar shape and size, up to $\sim 100 \mu \mathrm{m}$ beneath the slice surface.

\section{Electrophysiological Recordings}

Intracellular sharp microelectrode filled with $2 \mathrm{M} \mathrm{KCl}$ were used for current clamp recordings. The signal was acquired by an Axoclamp 2B amplifier (Axon Instruments). The traces were displayed on an oscilloscope (Gould Classic 6000), acquired, stored, and analyzed off-line by pClamp 9 software (Axon Instruments). During current-clamp experiments, the effect of 5-HT on membrane properties was determined after adjusting the membrane potential back to the resting value by injecting hyperpolarizing current into the recorded cell. Whole-cell patch clamp recordings were made with borosilicate glass pipettes $(1.8 \mathrm{~mm} \mathrm{o.d.;}$ 3-5 M $\Omega$ ) containing $(\mathrm{mM}) \mathrm{K}^{+}$-gluconate (125), $\mathrm{NaCl}(10)$, $\mathrm{CaCl}_{2}, \quad(1.0), \quad \mathrm{MgCl}_{2}$ (2.0), 1,2-bis (2-aminophenoxy) ethane- $N, N, N, N$-tetraacetic acid (BAPTA; 0.5$), N$-(2-hydroxyethyl)-piperazine- $N$-s-ethanesulfonic acid (HEPES; 19), guanosine triphosphate (GTP; 0.3), Mg-adenosine triphosphate (Mg-ATP; 1.0), adjusted to pH 7.3 with KOH. Membrane currents were monitored using an Axopatch 1D patch-clamp amplifier (Axon Instruments, Foster City, CA). Interneurons were voltage-clamped at $-60 \mathrm{mV}$. Voltage ramps and digital subtractions of the resulting currents were obtained by using pClamp 9 software. Voltage ramps (from -120 to $-40 \mathrm{mV}, 6 \mathrm{mV} / \mathrm{s}$ ) were preceded by a clamp at $-120 \mathrm{mV}$ for $2 \mathrm{~s}$ to allow $I_{\mathrm{h}}$ currents to develop. The instantaneous current response to the voltage step (before development of $I_{\mathrm{h}}$ currents) was used to estimate input resistance of the interneurons. Neurons in which series resistance $(8-25 \mathrm{M} \Omega$ ) changed by more than $10 \%$ during 5-HT application were discarded from the statistics.

Values given in the text and in the figures are mean $\pm S E M$ of changes in the respective cell populations. Nonparametric Wilcoxon matched pairs and Mann-Whitney test were used to compare the means.

\section{Drug Source and Handling}

Ketanserin, RS23597-190, SB 258585, ZD7288, chelerythrine, CNQX, D-APV, bicuculline, SB 269970, RS 102221, 5carboxamidotryptamine maleate (5-CT), isamoltane hemifumarate were from Tocris Cookson (Bristol, UK); tetrodotoxin (TTX), serotonin, 2,5-dimethoxy-4-iodoamphetamine (DOI), SQ22,536, calphostin C, tropisetron, barium chloride, and cesium chloride were from Sigma (Milan, Italy). Drugs were applied by dissolving them to the final concentration in the saline and by switching the perfusion from control saline to drug-containing saline, after a three ways tap had been turned on.

\section{Single-Cell RT-PCR Analysis}

Neurons were harvested using patch electrodes that had been baked at $200^{\circ} \mathrm{C}$ for $2 \mathrm{~h}$ before use. Sterile gloves were worn during the entire procedure to minimize RNase contamination. Electrodes contained $2.0 \mu \mathrm{l}$ of pipet solution or $1.64 \mu \mathrm{l}$ diethyl carbonate-treated water, $0.2 \mu \mathrm{l} 10 \times \mathrm{RT}$ buffer, $0.08 \mu \mathrm{l} \mathrm{MgCl}_{2}(25 \mathrm{mM}$ ), and $0.08 \mu \mathrm{l} \mathrm{RNaseOUT} \mathrm{(40} \mathrm{U/}$ $\mu \mathrm{l})$. All components were from Superscript III First-Strand Synthesis System (RT-PCR Kit \#18080-051, Invitrogen Life Technologies, Carlsbad, CA). Following aspiration, the tip of the electrode was broken and the contents ejected into a 
sterile Eppendorf tube containing $1.4 \mu \mathrm{l}$ diethyl carbonatetreated water, $0.5 \mu \mathrm{l} \mathrm{MgCl}_{2}(25 \mathrm{mM}), 1.0 \mu \mathrm{l}$ mixed dNTPs (10 mM), $0.7 \mu \mathrm{l}$ RNaseOUT ( $40 \mathrm{U} / \mu \mathrm{l}), 0.7 \mu \mathrm{lBSA}(143 \mu \mathrm{g} / \mu \mathrm{l})$, $0.7 \mu \mathrm{l}$ oligo-dT $(0.5 \mu \mathrm{g} / \mu \mathrm{l})$, and $1.0 \mu \mathrm{l}$ random hexamers $(50 \mathrm{ng} / \mu \mathrm{l})$. Single strand cDNA was synthesized from cellular mRNAs by heating the mixture to $65^{\circ} \mathrm{C}$ for $5 \mathrm{~min}$, then cooling on ice for $1 \mathrm{~min}$; then a mixture containing $1.0 \mu \mathrm{l} 10 \times \mathrm{RT}$ buffer, $1.5 \mu \mathrm{l} \mathrm{MgCl}_{2}(25 \mathrm{mM}), 1.0 \mu \mathrm{l}$ DTT $(0.1 \mathrm{M}), 0.5 \mu \mathrm{l}$ RNaseOut $(40 \mathrm{U} / \mu \mathrm{l})$ and $1.0 \mu \mathrm{l}$ Superscript III Reverse Transcriptase $(200 \mathrm{U} / \mu \mathrm{l})$ were added; the mixture was then incubated for $10 \mathrm{~min}$ at $25^{\circ} \mathrm{C}$ for primer binding; the reaction mixture was then held at $50^{\circ} \mathrm{C}$ for $1 \mathrm{~h}$ and $30 \mathrm{~min}$ to promote cDNA synthesis; the reaction was terminated by heating to $85^{\circ} \mathrm{C}$ for $5 \mathrm{~min}$ and then snap cooling $0^{\circ} \mathrm{C}$; lastly, RNase $\mathrm{H}(1 \mu \mathrm{l}, 2 \mathrm{U} / \mu \mathrm{l})$ was added and the mixture incubated at $37^{\circ} \mathrm{C}$ for $20 \mathrm{~min}$ to remove the RNA strand from RNA-cDNA hybrids. cDNAs were amplified by PCR using primers developed from GenBank sequences using commercially available software (OLIGO, National Biosciences, Plymouth, MN). Primers for choline acetyltransferase (ChAT) and the $67 \mathrm{kDa}$ isoform of glutamate decarboxylase (GAD67) have been described previously (Tkatch et al, 1998). The 5-HT1a mRNA (Genbank NM_008308) was detected with a pair of primers: upper primer CCAAGAAGAGCCTGAATGGT, lower primer TGG CAACTGCTCTCACAGAAA. The predicted PCR product length was $379 \mathrm{bp}$. The 5-HT2a mRNA (Genbank M30705) was detected with a pair of primers: upper primer TCGAG CCAAACTAGCCTCCTTCA, lower primer TTCTGTCCCA CCTGGAGCTGACTA. The predicted PCR product length was $465 \mathrm{bp}$. The 5-HT2C mRNA (Genbank, M21410) was detected with a pair of primers: upper primer GCCGT CAAACTCTGATGTTACTTC, lower primer ACGTTCATT GGTATGCCGATAA. The predicted PCR product length was $545 \mathrm{bp}$. The 5-HT6 mRNA (Genbank, NM_021358) was detected with a pair of primers: upper primer TTGTGGCCA GCATAGCTCAG, lower primer CCGGGTCGCCTCTCCAG. The predicted PCR product length was $343 \mathrm{bp}$. The 5-HT7 mRNA (Genbank, NM_L19654) was detected with a pair of primers: upper primer GGTGGAAGAGTGTGCGAACCT TTC, lower primer CGGGCCTCTCAGCAAGTTTCAG. The predicted PCR product length was $383 \mathrm{bp}$. Standard methods were employed for PCR product detection. The negative controls for contamination from extraneous and genomic DNA were run for every batch of neurons. Both controls were consistently negative in these experiments.

\section{RESULTS}

\section{Identification of the Recorded Neurons}

Physiological data were obtained from 224 neurons. Large, aspiny cholinergic interneurons were visualized with IRDIC videomicroscopy (up to $\sim 100 \mu \mathrm{m}$ beneath the surface) in striatal slices (Figure 1a). The electrophysiological properties of these neurons confirmed the morphological identification (Figure 1b-d) (Kawaguchi, 1993; Bennett and Wilson, 1999; Pisani et al, 2000). The recorded neurons had a mean resting membrane potentials of $-60.3 \pm 0.9 \mathrm{mV}$ and a high input resistance $(120.0 \pm 12.8 \mathrm{M} \Omega$, in intracellular sharp recordings; $78.5 \pm 3.7 \mathrm{M} \Omega$ in the whole-cell configuration). Action potential firing showed strong
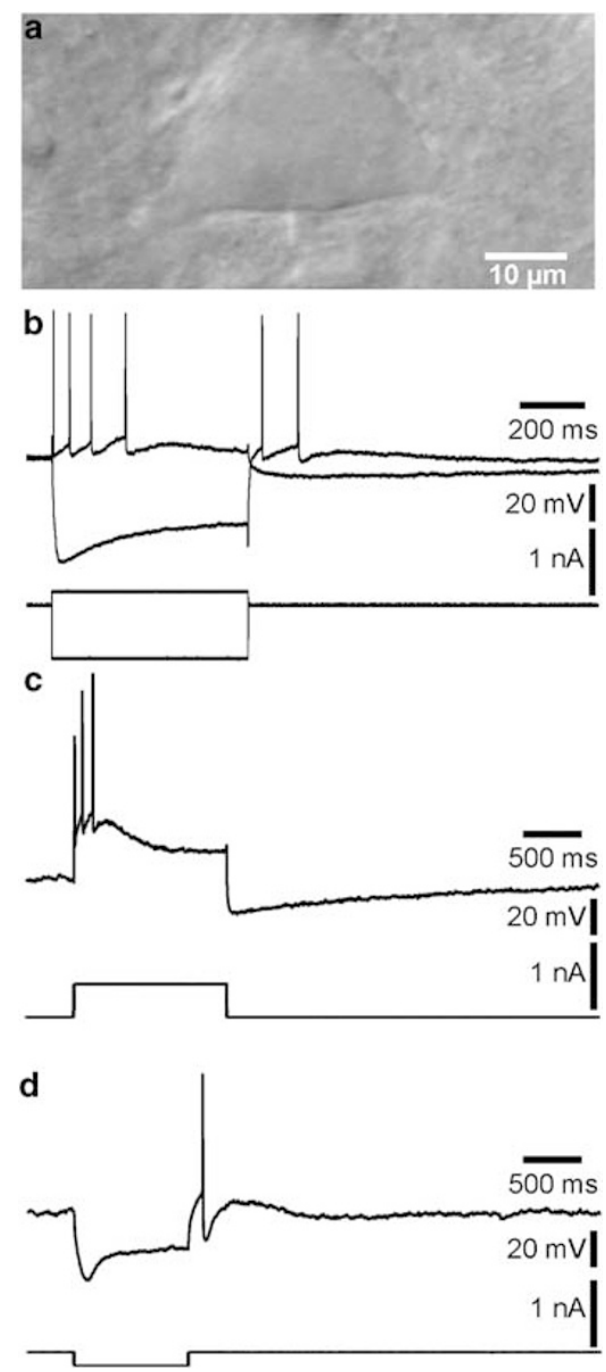

Figure I Morphological and electrophysiological features of striatal cholinergic interneurons. (a) DIC image of a cholinergic interneuron in a striatal slice showing a large sized, polygonal soma bearing two to three dendrites, peculiar features of this class of striatal cells. (b) In a representative recording, a short pulse of positive current (200pA, $600 \mathrm{~ms}$ ) induced a train of action potentials showing a strong accommodation. Note the pronounced AHP following the depolarizing step. In the same recording, injection of negative current $(800 \mathrm{pA}, 600 \mathrm{~ms})$ induced a typical sag in the membrane response, indicating a strong $I_{\mathrm{h}}$. $R M P=-57 \mathrm{mV}$. (c) By injecting a higher amount of positive current for longer duration ( $500 \mathrm{pA}, 1.3 \mathrm{~s})$ both firing accommodation and AHP were more evident. $R M P=-66 \mathrm{mV}$. (d) A prolonged pulse of negative current induced a strong time-dependent $I_{\mathrm{h}}$. RMP $=-58 \mathrm{mV}$.

accomodation and was followed by a long-lasting after hyperpolarization (AHP; $345 \pm 108 \mathrm{~ms}$ duration) (Figure $1 \mathrm{~b}$ and c). Hyperpolarizing current pulses evoked a prominent voltage sag, characteristic of an $I_{\mathrm{h}}$ current (Figure $1 \mathrm{~b}$ and d) (Jiang and North, 1991; Kawaguchi, 1993). All neurons included in this study showed these properties. Moreover, nearly half of the neurons displayed spontaneous spiking.

\section{5-HT-Induced Depolarization of Striatal Cholinergic Interneurons}

In the current-clamp condition, bath application of 5-HT $(0.3-300 \mu \mathrm{M})$ consistently depolarized interneurons and 
increased firing frequency (Figure 2a). The calculated mean frequency at rest was $1.8 \pm 0.2 \mathrm{~Hz}$. Bath application of $5-\mathrm{HT}$ $(10 \mu \mathrm{M}, 30 \mathrm{~s})$ caused a more than two-fold increase in the mean firing rate $(4.7 \pm 0.4 \mathrm{~Hz} ; 261 \pm 22 \%$ of control; $n=5$; $p<0.01)$. The depolarizing response to 5-HT was still observed in the presence of TTX $(1 \mu \mathrm{M})$, arguing that voltage-gated $\mathrm{Na}^{+}$channels were not obligatory targets of the modulation (Figure 2b; $n=47$ ). In addition, CNQX, APV $(10 \mu \mathrm{M}, n=3$ and $50 \mu \mathrm{M}, n=4$, respectively), and bicuculline $(30 \mu \mathrm{M}, n=3)$ - blockers of ionotropic glutamate receptors and $\mathrm{GABA}_{\mathrm{A}}$ receptors - failed to alter the effect of 5-HT (not shown; $p>0.05$ ). Taken together, these observations indicate that $5-\mathrm{HT}$ was acting at postsynaptic sites. The dose-response curve for the 5-HT-induced depolarizing effect reached a plateau at $50 \mu \mathrm{M}$ (Figure $2 \mathrm{c}$; Table 1), and was fitted by a logistic equation from which an $\mathrm{EC}_{50}$ value of $6.5 \pm 2.3 \mu \mathrm{M}$ was calculated (Figure $2 \mathrm{c} ; n=10$ ).

\section{5-HT Receptor Classes Involved in the Serotonergic Excitatory Response}

5-HT2 receptors are abundant in the striatum (Cassel and Jeltsch, 1995). The involvement of this class of receptors in the 5-HT-induced response of cholinergic interneurons was addressed by applying the 5-HT2 antagonist ketanserin in the bath. In the presence of TTX, ketanserin $(10-30 \mu \mathrm{M}$; 10-15 min preincubation) reversibly reduced the amplitude of the membrane depolarization induced by 5 -HT $(50 \mu \mathrm{M})$. The inhibitory effect observed with 10 and $30 \mu \mathrm{M}$ ketanserin were not statistically different and therefore data were pooled (Figure 3a, Table 1; $53.8 \pm 3.3 \%$ of control; $n=14$; $p<0.05)$. In line with these results, the selective 5 -HT2 agonist DOI $(20 \mu \mathrm{M}, 3 \mathrm{~min})$ induced a reversible membrane depolarization in the presence of TTX (Figure $3 b_{1}$, Table 1; $3.4 \pm 0.5 \mathrm{mV} ; n=10 ; p<0.01)$. The depolarizing response
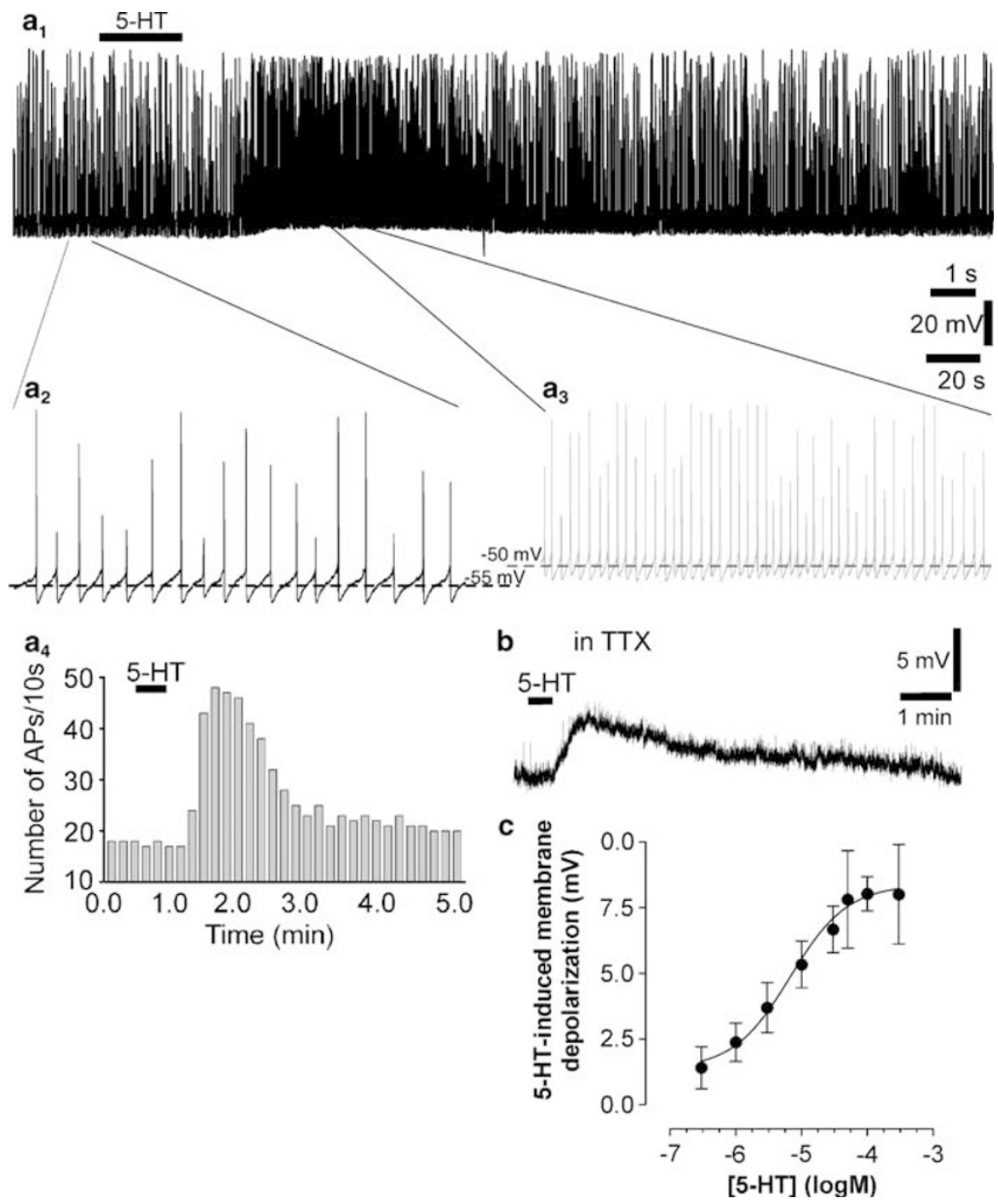

Figure $25-\mathrm{HT}$ excites striatal cholinergic interneurons. $\left(\mathrm{a}_{1}\right)$ In a spontaneously firing cholinergic interneuron, bath application of 5-HT (I0 $\mu \mathrm{M}$, 30 s) induced a membrane depolarization and increased the frequency of action potential discharge (shown at higher sweep speed in $\left(a_{2}\right)$ : pre- and $\left(a_{3}\right)$ : post-5$\mathrm{HT}) .\left(\mathrm{a}_{4}\right)$ Timecourse of the $5-\mathrm{HT}$-induced increase in discharge rate. RMP $=-50 \mathrm{mV}$. (b) In another representative recording, in the presence of $\mathrm{TTX}$ $(\mathrm{I} \mu \mathrm{M})$ the $5-\mathrm{HT}$-induced $(50 \mu \mathrm{M}, 30 \mathrm{~s})$ membrane depolarization was still observed. RMP $=-68 \mathrm{mV}$. (c) Dose-response curve of the 5-HT-induced membrane depolarization, in the presence of TTX. The $\mathrm{EC}_{50}$ calculated from this curve was $6.75 \pm 2.29 \mu \mathrm{M}$. 
Table I Summary of the Pharmacological Characterization of the Serotonergic Effects on Striatal Cholinergic Interneurons

\begin{tabular}{|c|c|c|c|c|c|}
\hline Drug & Target & $\mu \mathrm{M}$ & Effect & $\%$ of control & $N$ \\
\hline $5-\mathrm{HT}$ & & 50 & $\mathrm{MD}(8 . \mathrm{I} \pm 0.8 \mathrm{mV})$ & & 10 \\
\hline DOI & Agonist 5-HT2 & 20 & $\mathrm{MD}(3.4 \pm 0.5 \mathrm{mV})$ & & 10 \\
\hline Ketanserin & Antagonist 5-HT2A/C & $10-30$ & & $53.8 \pm 3.3$ & 14 \\
\hline RS I02221 & Antagonist 5-HT2C & $1-3$ & & $66.9 \pm 1.3$ & 4 \\
\hline Tropisetron & Antagonist 5-HT3 & 10 & & $98.7 \pm 2.1$ & 5 \\
\hline SB 269970 & Antagonist 5-HT7 & 3 & & $17.7 \pm 3.8$ & 7 \\
\hline $5-C T$ & Agonist 5-HTI/5-HT7 & 10 & $\mathrm{MD}(6.2 \pm 0.7 \mathrm{mV})$ & & 5 \\
\hline Fluvoxamine & Inhibitor of reuptake & 30 & $\mathrm{MD}(2.9 \pm 0.3 \mathrm{mV})$ & & 5 \\
\hline Citalopram & Inhibitor of reuptake & 30 & $\mathrm{MD}(4.2 \pm 0.8 \mathrm{mV})$ & & 12 \\
\hline
\end{tabular}

MD, membrane depolarisation.

induced by DOI $(20 \mu \mathrm{M}, 3 \mathrm{~min})$ was prevented by pretreatment with ketanserin $(10 \mu \mathrm{M}, 10-15 \mathrm{~min}$ preincubation; Figure $3 b_{2} ; 9.1 \pm 0.5 \%$ of control; $n=6 ; p<0.01$ ). In order to discriminate between 5 -HT2 receptor subtypes, the effect of the selective 5-HT2C antagonist RS 102221 was tested on the 5-HT-induced response (Xiang et al, 2005). Pretreatment with RS $102221(1-3 \mu \mathrm{M}, 10-15 \mathrm{~min})$ caused a significant reduction in the depolarization produced by $50 \mu \mathrm{M} 5$ - HT (Figure 3c, Table 1; $3 \mu \mathrm{M}: 66.9 \pm 1.3 \%$ of control; $n=4$; $p<0.05$ ); addition of $10 \mu \mathrm{M}$ ketanserin did not cause further inhibitory effect (Figure $3 c_{4} ; n=3 ; p>0.05$ ). These data indicate the involvement of 5-HT2C, but not 5-HT2A, receptor subtype in the 5-HT-induced depolarization of cholinergic interneurons.

Among other 5-HT receptor subtypes, 5-HT3 and 5-HT4 are expressed within the striatum (Blandina et al, 1989; Jakeman et al, 1994; Waeber et al, 1994; Patel et al, 1995; Gerald et al, 1995). Thus, in another set of experiments selective drugs acting both at 5-HT3 and 5-HT4 receptors were tested. Tropisetron $(10 \mu \mathrm{M}, 10 \mathrm{~min})$, a selective 5 -HT3 receptor antagonist, failed to alter the membrane depolarization/inward current caused by 5 -HT (Table $1 ; n=5$; $p>0.05)$. The 5-HT4 receptor antagonist RS 23597-190 $(25 \mu \mathrm{M})$ was applied in the perfusion solution $10-15 \mathrm{~min}$ before 5-HT ( $50 \mu \mathrm{M}, 30 \mathrm{~s})$ application. Pretreatment with RS 23597-190 did not significantly affect the amplitude of the 5-HT-induced membrane depolarization, thus ruling out an involvement of 5-HT4 receptors in the serotonergic excitation of cholinergic interneurons (Figure 4a, Table 1; $96.1 \pm 2.9 \%$ of control; $n=7 ; p>0.05$ ).

Another 5-HT receptor expressed at significant levels in the striatum is the 5-HT6 receptor (Ruat et al, 1993; Ward and Dorsa, 1996; Gerard et al, 1997). The involvement of these receptors was assessed by using the selective antagonist SB 258585. Pretreatment with SB 258585 $(1-30 \mu \mathrm{M})$ dose-dependently reduced the 5-HT-induced $(50 \mu \mathrm{M})$ membrane depolarization $(1 \mu \mathrm{M}: 75.1 \pm 2.8 \%$; $3 \mu \mathrm{M}: 62.6 \pm 2.1 ; 10 \mu \mathrm{M}: 49.5 \pm 3.7 \% ; 30 \mu \mathrm{M}: 53.9 \pm 2.9$ of control, respectively; $n=9 ; \quad p<0.01)$, with a maximal inhibition observed at $10 \mu \mathrm{M}$ (Figure $4 \mathrm{~b}$, Table 1). These observations indicate that 5-HT6 receptors contribute to the excitatory effect of 5-HT on cholinergic interneurons.
5-HT7 receptor expression level has been previously reported to be low in the rat striatum (Vizuete et al, 1997; Hoyer et al, 2002). We tested the effect of the selective 5-HT7 receptor antagonist SB $269970(1-3 \mu \mathrm{M}, 20-25 \mathrm{~min})$ on the 5-HT-induced depolarizing response (Chapin and Andrade, 2001). SB 269970 showed a significant inhibitory effect on the depolarization induced by 5 -HT $(50 \mu \mathrm{M}, 30 \mathrm{~s})$ in striatal cholinergic interneurons (Figure $5 \mathrm{a}$, Table 1; $17.7 \pm 7 \%$ of control; $n=7 ; p<0.05)$. Accordingly, 5 -CT (agonist at 5-HT1 and 5-HT7 receptors; $10 \mu \mathrm{M}, 1 \mathrm{~min}$ ) induced a membrane depolarization, that was unaffected by preincubation of the slice with isamoltane $(1 \mu \mathrm{M})$, selective 5-HT1B antagonist (Table $1 ; 6.2 \pm 0.7 \mathrm{mV} ; n=5 ; p<0.01$ ). The 5-CT-induced membrane response was slightly reduced by addition of ketanserin and SB 258585 (both $10 \mu \mathrm{M}$ ) (Figure $5 b_{2} ; 70.1 \pm 2.2 \%$ of control; $n=4 ; p>0.05$ ). Further addition of $3 \mu \mathrm{M}$ SB 269970 completely abolished the 5-CTinduced response (Figure $5 b_{3} ; 7.0 \pm 1.2 \%$ of control; $n=4$; $p<0.05$ ).

The depolarizing response induced by 5 -HT $(50 \mu \mathrm{M}, 30 \mathrm{~s})$ was abolished by coapplication of RS 102221, SB 258585, and SB 269970 (Figure $6 \mathrm{a}_{4} ; 14.5 \pm 3.2 \%$ of control; $n=3$; $p<0.05$ ), thus confirming the involvement of 5-HT2C, 5-HT6, and 5-HT7 receptors in the serotonergic excitation of striatal cholinergic interneurons.

\section{Striatal Cholinergic Interneurons Express 5-HT2C, 5-HT6, and 5-HT7 Receptors}

The pharmacological data suggest that 5-HT2C, 5-HT6, 5-HT7 receptors are involved in the serotonergic response. Previous studies have reported the expression of almost all 5-HT receptor subtypes in the striatum (Blandina et al, 1989; Jakeman et al, 1994; Waeber et al, 1994; Bruinvels et al, 1994; Patel et al, 1995; Gerald et al, 1995; Ward and Dorsa, 1996). However, the 5-HT receptors expressed by striatal cholinergic interneurons are unknown. To answer this question, single-cell RT-PCR (scRT-PCR) profiling was performed for 5-HT receptor mRNAs. Neurons were identified by their expression of choline acetyltransferase mRNA. Accordingly, they were negative for both substance $\mathrm{P}$ and enkephalin mRNA expression. Neurons were profiled 
$\mathbf{a}_{1}$

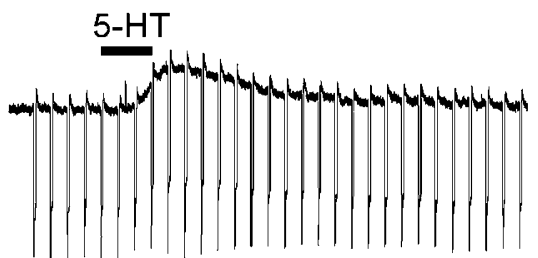

$a_{2}$

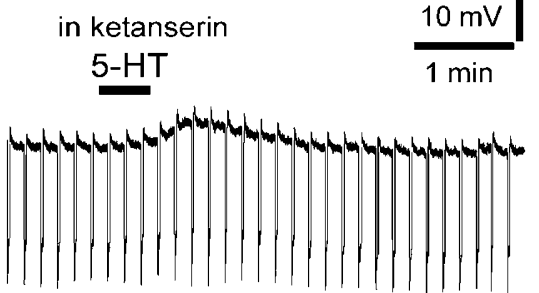

$\mathbf{b}_{1}$

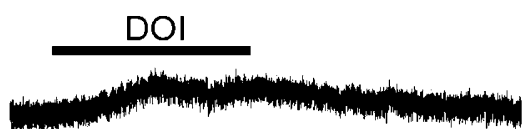

$\mathbf{b}_{2}$

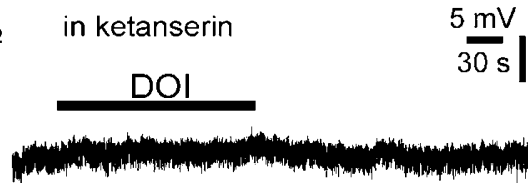

$\mathbf{C}_{1}$

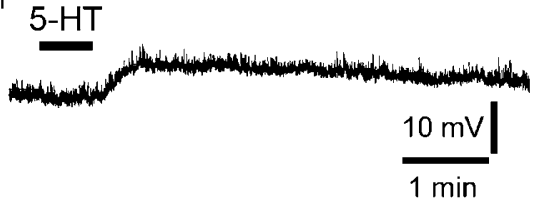

$\mathbf{C}_{2} \quad$ in $1 \mu \mathrm{M}$ RS 102221

$5-\mathrm{HT}$

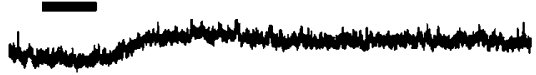

$\mathrm{C}_{3}$

in $3 \mu \mathrm{M}$ RS 102221

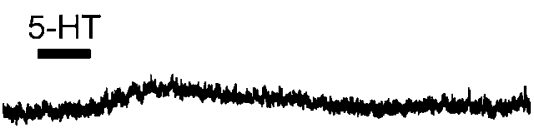

$\mathbf{C}_{4} \quad$ in $3 \mu \mathrm{M}$ RS 102221

plus ketanserin

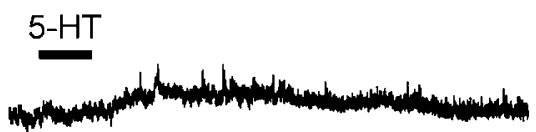

Figure 3 The serotonergic excitation of cholinergic interneurons involves 5-HT2C receptor activation. ( $\mathrm{a}_{1}$ ) In a representative recording from a cholinergic interneuron, in the presence of TTX, bath application of 5-HT (black bar; $50 \mu \mathrm{M}, 30 \mathrm{~s}$ ) induced a membrane depolarization. Downward deflections represent the voltage response to hyperpolarizing current steps (200 pA, I.5 s). ( $\left.\mathrm{a}_{2}\right)$ Pretreatment with the 5 -HT2 antagonist ketanserin $(30 \mu \mathrm{M}$, $15 \mathrm{~min})$ reduced the amplitude of the 5-HT-induced membrane depolarization. RMP $=-67 \mathrm{mV}$. ( $\left.\mathrm{b}_{1}\right)$ Bath-application of the 5-HT2 agonist DOI (20 $\mu \mathrm{M}$, $3 \mathrm{~min}$ ) mimicked the 5-HT-induced membrane depolarization. $\left(b_{2}\right)$ Preincubation in ketanserin abolished the DOI response. RMP $=-60 \mathrm{mV}$. (c) Representative recording showing the inhibitory effect of the selective 5-HT2C antagonist RS I0222I ( $\mathrm{c}_{2}:$ I $\mu \mathrm{M}, \mathrm{c}_{3}: 3 \mu \mathrm{M}$, I5 min) on the 5-HT depolarization $\left(c_{1}\right)$. $\left(c_{4}\right)$ Addition of ketanserin $(10 \mu \mathrm{M})$ did not cause further inhibitory effect. RMP $=-65 \mathrm{mV}$.

$a_{1}$

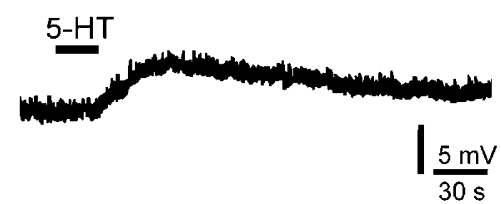

$\mathbf{a}_{2}$

in RS 23597-190

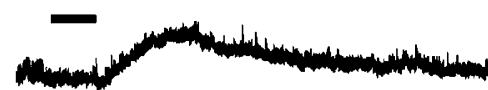

$\mathbf{b}_{1}$
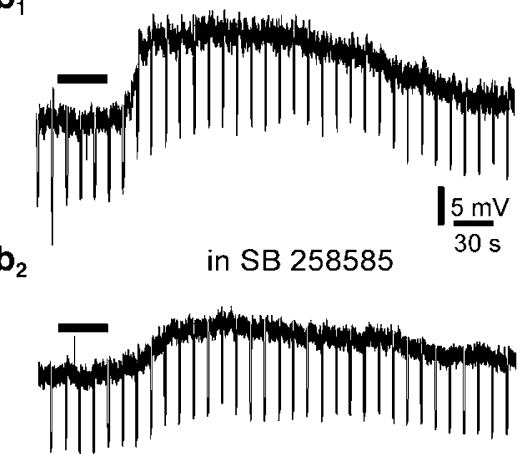

Figure 4 The 5-HT-induced depolarization is reduced by the selective 5-HT6 receptor antagonist SB 258585, but not by 5-HT4 receptor blockade. (a ) In a representative recording from a cholinergic interneuron, $50 \mu \mathrm{M} 5-\mathrm{HT}$ (black bar; $30 \mathrm{~s}$ ) induced a membrane depolarization. ( $\mathrm{a}_{2}$ ) Preincubation with the selective 5-HT4 antagonist RS 23597-190 (25 $\mathrm{M}$, I $5 \mathrm{~min}$ ) did not significantly modify the amplitude of the 5-HT-induced membrane depolarization. $\mathrm{RMP}=-65 \mathrm{mV}$. (b) Another recording showing the inhibitory effect of the selective 5-HT6 antagonist SB 258585 on the 5-HT-induced (black bar, $50 \mu \mathrm{M}$, $35 \mathrm{~s})$ membrane depolarization in a cholinergic interneuron. The downward deflections represent the membrane response to current pulses (I00 pA, I.5 s), applied to evaluate the membrane resistance. $\left(b_{2}\right)$ After 15 min pretreatment with the 5-HT6 receptor antagonist SB 258585 (I0 $\mu M$ ) the amplitude of $5-H T$-induced depolarization was significantly reduced. RMP $=-59 \mathrm{mV}$.

for their expression of 5-HT1, 5-HT2A, 5-HT2C, 5-HT6, and 5-HT7 receptor mRNAs (Figure 7). 5-HT2C (16/21) and 5-HT6 (11/21) receptor mRNAs were readily detected in striatal cholinergic interneurons. On the other hand, 5-HT1 class transcripts were only detected in less than a third (7/21) of the neurons and 5-HT2A mRNA was only detected once (1/21). The 5-HT7 receptor detection rate was high (11/15). Figure 7b summarizes the detection frequencies of 5-HT receptor subtype mRNA in cholinergic interneurons. 


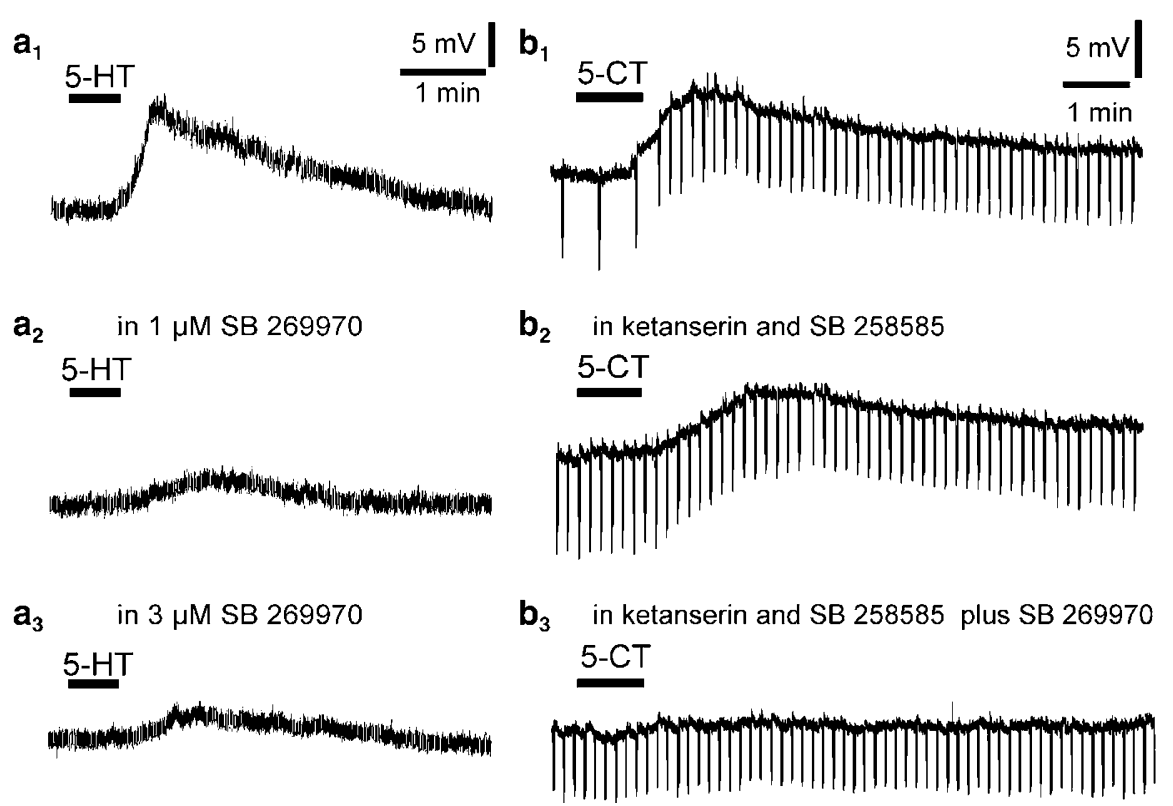

Figure 5 5-HT7 receptor contributes to the 5-HT effect on cholinergic interneurons. $\left(\mathrm{a}_{2}\right)$ Representative trace showing the strong inhibitory effect of the selective 5-HT7 antagonist SB 269970 (I $\mu \mathrm{M}, 25 \mathrm{~min}$ ) on the 5-HT-induced (black bar, $50 \mu \mathrm{M}, 35 \mathrm{~s}$ ) depolarization of cholinergic interneurons. ( $\mathrm{a}_{3}$ ) Note that increasing the concentration of SB 269970 to $3 \mu \mathrm{M}$ did not exert further inhibitory effect. RMP $=-54 \mathrm{mV}$. ( $\left.b_{1} b_{3}\right)$ In the presence of the 5 - $\mathrm{HTI}$ antagonist isamoltane ( $1 \mu \mathrm{M}, I 5 \mathrm{~min}$ ), the 5-HTI and 5-HT7 agonist 5-CT (black bar, I0 $\mu \mathrm{M}, 1 \mathrm{~min}$ ) induced a depolarizing response in the recorded cholinergic interneuron. The downward deflections represent the voltage response to current pulses ( $100 \mathrm{pA}, 1.5 \mathrm{~s})$. ( $\left.\mathrm{b}_{2}\right) \mathrm{Addition}$ of I $0 \mu \mathrm{M}$ ketanserin and I 0 MM SB 258585 did not cause significant inhibitory effect. $\left(b_{3}\right)$ The selective 5-HT7 antagonist SB 269970 ( I $\mu$ M) completely blocked the 5-CT-induced depolarizing effect. $\mathrm{RMP}=-63 \mathrm{mV}$.

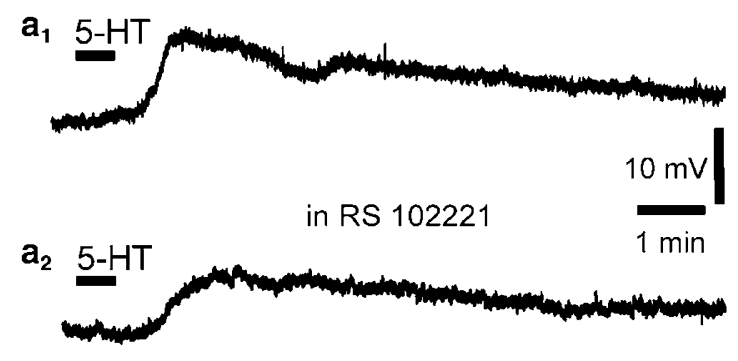

in RS 102221 plus SB 258585

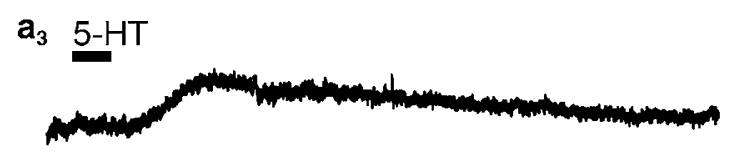

in RS 102221 and SB 258585

$\mathbf{a}_{4}$ 5-HT plus SB 269970

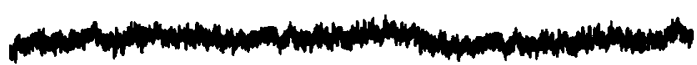

Figure 6 The 5-HT-induced depolarization of striatal cholinergic interneurons is mediated by $5-\mathrm{HT} 2 \mathrm{C}, 5-\mathrm{HT} 6$, and $5-\mathrm{HT} 7$ receptors. $\left(\mathrm{a}_{4}\right)$ Representative recording showing that only coadministration of the selective antagonists at 5-HT2C receptor, $3 \mu \mathrm{M}$ RS I0222I, 5-HT6 receptor, $10 \mu \mathrm{M}$ SB 258585, and 5-HT7 receptor, I $\mu$ M SB 269970, completely blocked the 5-HT-induced membrane depolarization ( $\mathrm{a}_{1}$, black bar, $50 \mu \mathrm{M}, 35 \mathrm{~s})$. RMP $=-63 \mathrm{mV}$.

\section{Endogenous Serotonergic Tone in the Striatum}

To address the possibility of an endogenous 5 -HT tone in the striatum, the effect of 5-HT reuptake inhibitors was

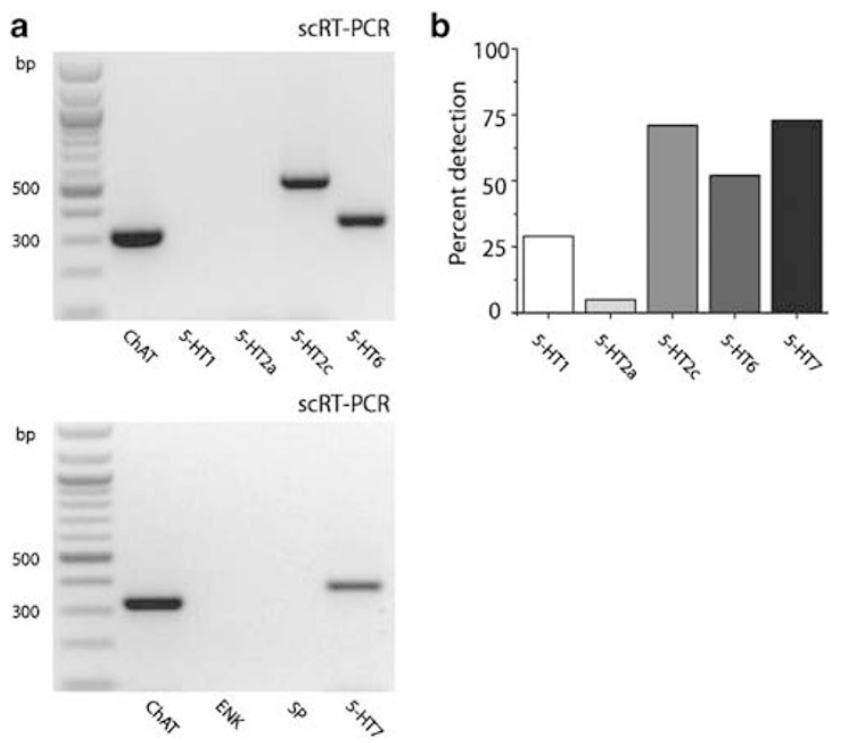

Figure 7 scRT-PCR of acutely isolated cholinergic interneuron revealed high expression of 5-HT2C, 5-HT6, and 5-HT7 mRNAs. (a) Ethidium bromide-stained gels showing SCRT-PCR profiles of typical interneurons, identified by ChAT staining (top) and absence of enkephalin and substance $\mathrm{P}$ staining (bottom). The upper gel shows a neuron coexpressing 5-HT2C and 5-HT6 mRNAs. The lower gel shows a cell with detectable 5-HT7 mRNA. (b) Summary of detection percentages for each mRNA in a sample of 36 cholinergic interneurons.

tested on cholinergic interneurons in our slice preparation. In the current-clamp mode, bath application of fluvoxamine $(30 \mu \mathrm{M}, 3 \mathrm{~min})$ induced a small, but significant membrane depolarization in the recorded cells (Figure 8a; $2.9 \pm 0.3 \mathrm{mV}$; 
$n=5 ; p<0.01)$. In spontaneously firing neurons the membrane depolarization was coupled to an increase in the frequency of action potentials (Figure 8a). Bathapplication of a more selective 5-HT reuptake inhibitor, citalopram $(30 \mu \mathrm{M}, 4 \mathrm{~min})$, induced a similar membrane depolarization (Figure $8 \mathrm{~b} ; 3.4 \pm 0.5 \mathrm{mV} ; n=18$ ), and increased the firing rate of the recorded interneurons $(178.1 \pm 11.1 \%$ of control; $p<0.01)$.

The contribution of 5-HT receptor subtypes to the response induced by inhibition of the reuptake was investigated pharmacologically by utilizing the selective 5-HT2, 5-HT6, and 5-HT7 antagonists. Treatment with either antagonist, per se, reduced the frequency of spontaneous firing activity without affecting the membrane potential (Figure 8c-e). In agreement with our pharmacological characterization, the membrane depolarization induced by citalopram ( $30 \mu \mathrm{M}, 4 \mathrm{~min})$ was significantly reduced by preincubation with the 5-HT2 antagonist ketanserin $(10 \mu \mathrm{M}, 15 \mathrm{~min}$ ) (Figure $8 \mathrm{c} ; 79.9 \pm 4.8 \%$ of control; $n=8$; $p<0.05)$ or the selective 5-HT2C antagonist RS $102221(3 \mu \mathrm{M}$, 10-15 min) (not shown; $n=3$ ). Similarly, both the 5-HT6 antagonist SB $258585(10 \mu \mathrm{M}, 10-15 \mathrm{~min})$ (Figure $8 \mathrm{~d}$; $71.2 \pm 4.2 \%$ of control; $n=4 ; p<0.05)$ and the 5-HT7 antagonist SB $269970(3 \mu \mathrm{M}, 20 \mathrm{~min}$ ) (Figure $8 \mathrm{e} ; 68 \pm 3.7 \%$ of control; $n=3 ; p<0.05)$ significantly reduced the membrane depolarization induced by citalopram. Accordingly, also the increase in firing frequency induced by citalopram was nearly abolished by any of the inhibitors (Figure 8).
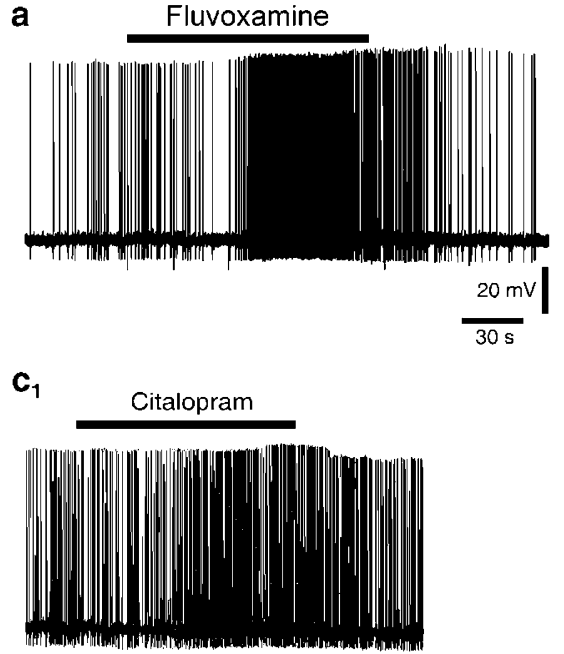

$\mathrm{d}_{1}$

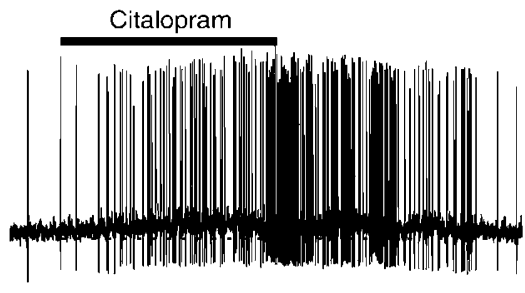

$\mathbf{e}_{1}$

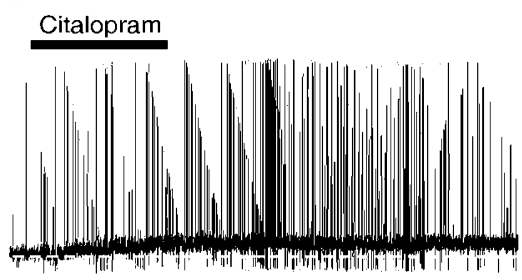

b

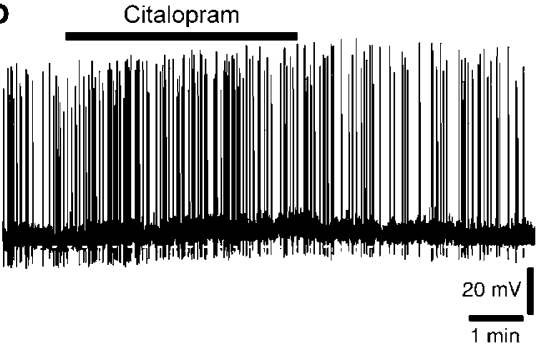

$\mathbf{C}_{2}$ in ketanserin

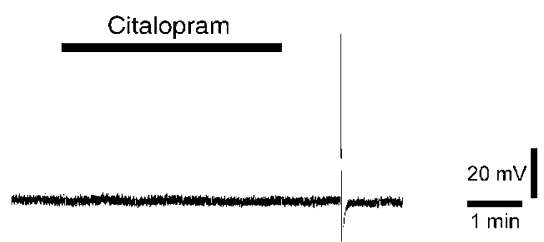

$\mathbf{d}_{\mathbf{2}}$ in SB 258585
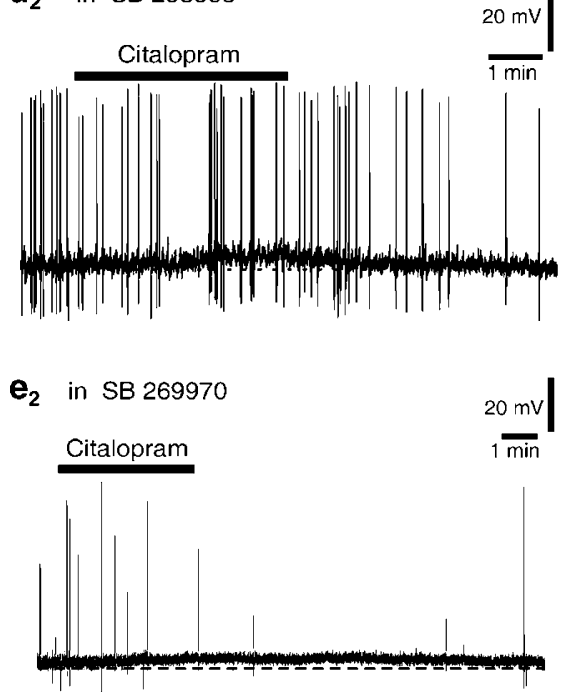

Figure 8 Endogenous serotonergic tone in the striatum. (a) Representative trace of a recording from a spontaneously firing cholinergic interneuron. Inhibition of the 5-HT reuptake by fluvoxamine (black bar, $10 \mu \mathrm{M}, 2 \mathrm{~min}$ ) slightly depolarized the cell and increased firing frequency. RMP $=-59 \mathrm{mV}$. (b) $\mathrm{A}$ similar effect was observed using the highly selective 5-HT reuptake inhibitor citalopram (black bar, $30 \mu \mathrm{M}, 4 \mathrm{~min}$ ). RMP $=-65 \mathrm{mV}$. (c) Ketanserin (I $0 \mu \mathrm{M}$, $10 \mathrm{~min}$ ) was able to significantly reduce the membrane depolarization and the increase in action potential firing induced by bath application of citalopram. The train of action potentials shown in $\left(c_{2}\right)$ was induced by injection of a current pulse. RMP $=-6 \mathrm{I} \mathrm{mV}$. (d) After pretreatment with SB 258585 (I0 $\mu$ M, $15 \mathrm{~min}$ ), the citalopram-induced depolarization and firing frequency increase were significantly reduced. RMP $=-68 \mathrm{mV}$. (e) In another spontaneously firing neuron, SB 269970 ( I MM, 20 min) significantly reduced both the membrane depolarization and the increase in firing frequency induced by citalopram. $\mathrm{RMP}=-50 \mathrm{mV}$. 


\section{Post-Receptor Transduction Pathway of the 5-HT Effects}

5-HT6 and 5-HT7 receptors are positively coupled to adenylyl cyclase activation through $\mathrm{G}_{s}$ protein. Given the contribution of this receptor subtypes to the 5-HT-induced response, we tested for the involvement of adenylyl cyclase pathway in the 5-HT-induced depolarization. Pretreatment with the adenylyl cyclase inhibitor SQ22,536 $(50 \mu \mathrm{M}$, $20 \mathrm{~min}$ ) significantly reduced the 5 -HT-induced membrane depolarization (Figure 9; 60.2 $\pm 11.4 \%$ of control, $n=6$; $p<0.05$ ), thus confirming the involvement of adenylate cyclase. Elevations in cAMP lead to activation of protein kinase A (PKA). We therefore examined the involvement of PKA in the 5-HT response using the PKA inhibitor, $\mathrm{H}$-89. Pretreatment of the slice with $10 \mu \mathrm{M} \mathrm{H}-89$ did not significantly affect the amplitude of the depolarizing response to 5-HT (Figure 9; 101.6 $\pm 6.9 \%$ of control, $n=4$; $p>0.05)$. These results suggest that the response induced by 5-HT in cholinergic interneurons, similarly to what reported for the $\beta 1$ adrenoceptor, involves, at least in part, a cAMP-, but not PKA-sensitive element (Pisani et al, 2003).

5-HT receptors belonging to the 5-HT2 class are coupled to $G_{q}$ proteins and phospholipase C (PLC) activation. To test the involvement of PLC, slices were preincubated with the PLC inhibitor $\mathrm{U} 73122(10 \mu \mathrm{M}, \sim 15 \mathrm{~min})$. This led to a significant reduction in the depolarizing response to bath application of $50 \mu \mathrm{M}$ 5-HT (Figure 9; $59.6 \pm 4.9 \%$ of control, $n=3 ; p<0.05)$. PLC activation leads to the production of diacylglycerol and the activation of protein kinase $C$ (PKC). To test for PKC involvement, the inhibitors chelerythine $(3 \mu \mathrm{M})$ and calphostin $\mathrm{C}(1 \mu \mathrm{M})$ were used. The 5-HTinduced membrane depolarization was not significantly affected by pretreatment of the slice with neither of the two PKC inhibitors (Figure 9; $96 \pm 2.6 \%$ of control; $n=7$; $p>0.05)$.

\section{Mechanisms of Serotonergic Excitation of Striatal Cholinergic Interneurons}

To address the ionic mechanism mediating the depolarizing response to 5-HT, voltage-clamp recordings were performed in the whole-cell configuration in the presence of $1 \mu \mathrm{M}$ TTX. A concentration of $30 \mu \mathrm{M} 5-\mathrm{HT}$ was used for all voltage-clamp experiments. With the somatic membrane

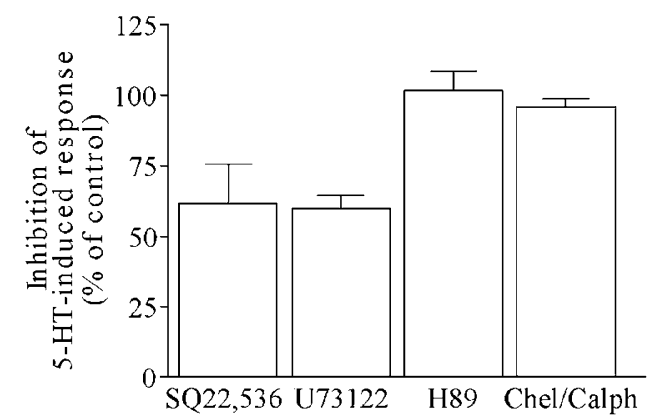

Figure 9 5-HT post-receptor transduction pathway. Summary plot of the effects of the inhibition of adenylyl cyclase, PLC, PKA, and PKC by, respectively, $300 \mu \mathrm{M}$ SQ22,536, I0 $\mu \mathrm{M} \cup 73122,10 \mu \mathrm{M} \mathrm{H}-89,3 \mu \mathrm{M}$ chelerythine or $1 \mu \mathrm{M}$ calphostin $\mathrm{C}$, on the 5-HT-induced membrane depolarization of striatal cholinergic interneurons. potential clamped at $-60 \mathrm{mV}, 5-\mathrm{HT}$ evoked an inward current $\left(I_{5-\mathrm{HT}}\right)$ with an average amplitude of $85.2 \pm 6.1 \mathrm{pA}$ (Figure $10 \mathrm{a}_{1}, n=14$ ). Slow voltage ramps from $-120 \mathrm{mV}$ to $-40 \mathrm{mV}(6 \mathrm{mV} / \mathrm{s})$ were applied in the absence and presence of 5-HT. $I_{5-\mathrm{HT}}$ was associated with a small increase in input resistance $(104.9 \pm 1.6 \%$ of control; $p<0.05)$. The reversal potential for $I_{5-\mathrm{HT}}\left(E_{5-\mathrm{HT}}:-105.1 \pm 4.3 \mathrm{mV}\right.$; Figure $\left.10 \mathrm{a}_{2}\right)$ was close to the $\mathrm{K}^{+}$equilibrium potential $\left(E_{\mathrm{K}_{+}}\right.$: $\left.-102 \mathrm{mV}\right)$ predicted by the Nernst equation. This finding suggests a main contribution of $\mathrm{K}^{+}$currents in the response of striatal cholinergic interneurons to 5 -HT. To test this possibility further, $E_{5-\mathrm{HT}}$ was measured at a higher extracellular $\mathrm{K}^{+}$ concentration. An increase to $7.5 \mathrm{mM} \mathrm{K}^{+}$caused a shift of $E_{5 \text {-HT }}$ towards less negative values $(-84.8 \pm 8.4 \mathrm{mV}$; Figure $10 \mathrm{~b} ; n=4$ ), confirming that $I_{5-\mathrm{HT}}$ is mediated by the closing of $\mathrm{K}^{+}$-selective ion channels.

The involvement of $\mathrm{K}^{+}$conductance in the 5-HT action was also examined in a second series of experiments in which $\mathrm{Ba}^{2+}(1 \mathrm{mM})$ was included in the perfusion solution to block $\mathrm{K}^{+}$channels. Extracellular $\mathrm{Ba}^{2+}$ increased input resistance $(214.9 \pm 17.4 \%$ of control; $n=7 ; p<0.001)$. In the presence of $1 \mathrm{mM} \mathrm{Ba}{ }^{2+}$, 5-HT application caused a slight decrease in input resistance $(90.7 \pm 3.3 \%$ of control; $n=7$; $p<0.05)$ and the amplitude of $I_{5-\mathrm{HT}}$ was significantly reduced $(51.6 \pm 3.1 \mathrm{pA}$; not shown; $p<0.01)$. Digital subtraction of the $I-V$ curves showed no reversal in the voltage range between -120 and $-40 \mathrm{mV}$ for the net 5-HT-induced current recorded in the presence of $1 \mathrm{mM} \mathrm{Ba}^{2+}$ (Figure 10c; $n=7$ ). The observed small decrease in input resistance and the absence of a reversal for the 5-HT-induced current in the voltage range examined suggest that, in addition to a reduction of $\mathrm{K}^{+}$conductance, 5- $\mathrm{HT}$ may also act by opening cation channels in striatal cholinergic interneurons.

The HCN channels expressed by cholinergic interneurons are modulated by cytosolic cAMP, making them potential mediators of the response to G-protein coupled receptors positively coupled to adenylyl cyclase, like the 5-HT6 and 5-HT7 receptors. To determine whether 5-HT modulates $I_{\mathrm{h}}$, we applied hyperpolarizing voltage steps (from -60 to $-120 \mathrm{mV} ; 2 \mathrm{~s}) . I_{\mathrm{h}}$ was defined as the difference between the steady-state current at the end of the voltage step and the instantaneous current (Figure $10 \mathrm{~d}_{1}$ ). Bath application of 5 -HT slightly reduced $I_{\mathrm{h}}$ (Figure $10 \mathrm{~d}_{1} ; 87.2 \pm 1.6 \%$ of control; $p<0.01 ; n=10)$. Preincubation of slices with the HCN channel blocker ZD7288 $(25 \mu \mathrm{M})$ abolished $I_{\mathrm{h}}(8.6 \pm 2.6 \%$ of control; not shown; $n=7 ; p<0.01)$ and increased input resistance $(133.0 \pm 10.2 \%$ of control; $n=7 ; p<0.01)$ (Bennett et al, 2000; Wilson, 2005). After ZD7288 preincubation, 5-HT induced a small increase in input resistance $(107 \pm 1.2 \%$ of control; $n=7 ; p<0.01)$ and the 5-HT-induced current showed a reversal potential of $-107.7 \pm 3.6 \mathrm{mV}$ (Figure $10 \mathrm{~d}_{2} ; n=7$ ). In the presence of ZD7288, a significant reduction of $I_{5-\mathrm{HT}}(37.0 \pm 7.7 \mathrm{pA}$; $p<0.001$; not shown) was observed. However, the possibility of aspecific effects of ZD7288 on this neuronal type should be considered (Wilson, 2005).

In another set of experiments $\mathrm{Cs}^{+}$was used to block HCN channels. $\mathrm{Cs}^{+}$has been reported to effectively reduce both $I_{\mathrm{h}}$ and inward rectifying $\mathrm{K}^{+}$(Kir) currents (Bennett et al, 2000; Kjaerulff and Kiehn, 2001; Wilson, 2005). Preincubation of the slices with $3 \mathrm{mM} \mathrm{Cs}^{+}$significantly 

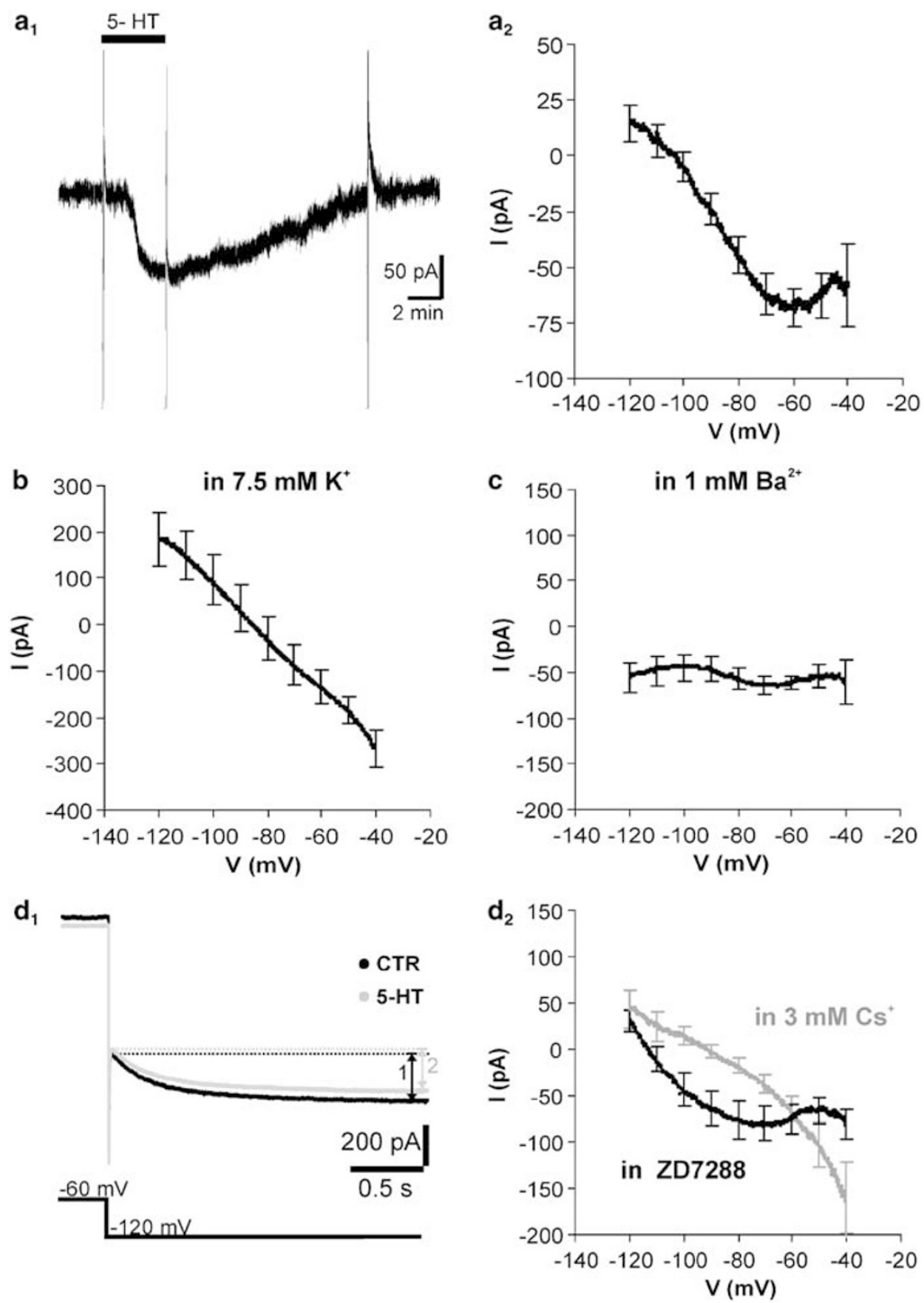

Figure 10 The 5-HT-induced inward current is mainly mediated by a potassium conductance. $\left(\mathrm{a}_{1}\right)$ Representative trace of the inward current induced by $5-\mathrm{HT}$ in voltage-clamped interneurons (holding potential $-60 \mathrm{mV}$ ). The downward deflections represent voltage ramps (from -120 to $-40 \mathrm{mV}$ ) applied before, during the maximal effect of $5-\mathrm{HT}(30 \mu \mathrm{M})$, and at drug washout. $\left(\mathrm{a}_{2}\right)$ Mean net 5-HT-induced current generated by digital subtraction from voltage ramps of I 4 interneurons. A negative reversal potential of the 5-HT-induced current, close to the $\mathrm{K}^{+}$equilibrium potential, is observed. (b) Mean net 5-HTinduced current obtained from digital subtraction of voltage ramps recorded in the presence of a higher extracellular $\mathrm{K}^{+}$concentration $(7.5 \mathrm{mM})$ from four interneurons. Note that the reversal potential is shifted to the right. (c) Mean net 5-HT-induced current generated by digital subtraction from voltage ramps recorded in the presence of high $\mathrm{Ba}^{2+}$ concentration $(1 \mathrm{mM})$ from seven interneurons. $\left(d_{1}\right)$ Representative current response of interneurons to a hyperpolarizing voltage step from -60 to $-120 \mathrm{mV}(2 \mathrm{~s})$. I $\mathrm{h}$ amplitude was defined as the difference between the steady-state current at the end of the voltage step and the instantaneous current. Compared to control (I, black line), In is reduced in the presence of 5-HT $\left(2\right.$, grey line). ( $\left.\mathrm{d}_{2}\right)$ Mean net 5-HTinduced current generated by digital subtraction from voltage ramps recorded in the presence of either $25 \mu M$ ZD7288 (black line, $n=7$ ) or $3 \mathrm{mM}$ Cs ${ }^{+}$ (grey line, $n=7$ ). In the presence of $\mathrm{Cs}^{+}$, the mean reversal potential of the net 5 -HT-induced current is shifted to the right. For clarity, SEM is not shown for all data points.

reduced $I_{\mathrm{h}}(15.6 \pm 2.4 \%$ of control; not shown; $n=8$; $p<0.05)$ and increased input resistance of the recorded cells $(210 \pm 16 \%$ of control; $n=8)$. In the presence of $\mathrm{Cs}^{+}, 5-\mathrm{HT}$ induced a significant increase in input resistance $(148 \pm 14 \%$ of control; $n=8 ; p<0.05)$ and the reversal of the 5-HT-induced current shifted to $-88 \pm 2.6 \mathrm{mV}$
(Figure $10 \mathrm{~d}_{2}$ ). Preincubation of the slices with $\mathrm{Cs}^{+}$did not significantly affect $I_{5-\mathrm{HT}} \quad(76.9 \pm 18.5 \mathrm{pA}$; not shown; $p>0.05)$. The reversal potential of the $\mathrm{Cs}^{+}$insensitive conductance suggests an involvement of $\mathrm{K}^{+}$channels that are not blocked by $\mathrm{Cs}^{+}$in the $5-\mathrm{HT}$ induced response. 

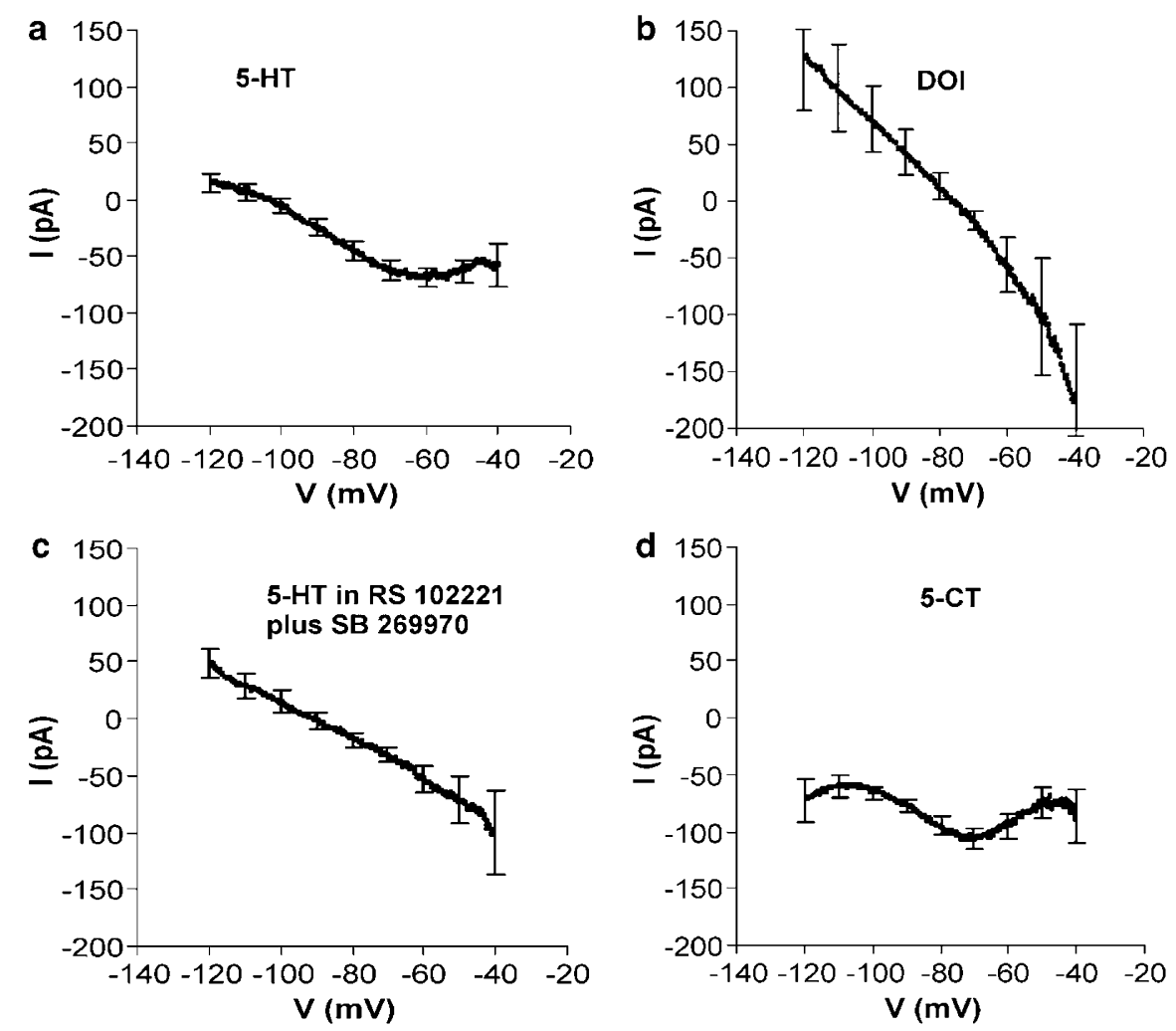

Figure II lon current induced by selective activation of 5-HT2C, 5-HT6 or 5-HT7 receptor subtype. (a-d) Mean net currents obtained by digital subtraction of voltage ramps delivered before and at the maximal effect of (a) $30 \mu \mathrm{M} 5-\mathrm{HT}$, (b) the 5-HT2 agonist DOI (20 $\mu \mathrm{M}$ ), (c) $30 \mu \mathrm{M} 5$ - HT plus 5 HT2C and 5-HT7 antagonists, $3 \mu \mathrm{M}$ RSI0222I and $3 \mu \mathrm{M} \mathrm{SB269970,} \mathrm{respectively,} \mathrm{(d)} \mathrm{the} \mathrm{5-HT7} \mathrm{agonist} \mathrm{5-CT} \mathrm{(I0} \mu \mathrm{M}$ ). (b) From the net DOI-induced current a mean reversal potential of $-79.4 \pm 2.4 \mathrm{mV}$ was calculated $(n=7)$. (c) In order to selectively activate 5-HT6 receptor, 5-HT was applied in the presence of 5-HT2C and 5-HT7 antagonists, RSI0222I and SB269970, respectively. From the current-voltage curve, a mean reversal potential of $-91.7 \pm 3.7 \mathrm{mV}$ was calculated $(n=8)$. (d) The current induced by $5-\mathrm{HTT}$ receptor agonist $5-\mathrm{CT}$ did not show a reversal potential in the voltage range examined $(n=6)$. For clarity, SEM is not shown for each data point.

In conclusion, these data show that closure of $\mathrm{K}^{+}$selective channels primarily accounts for the inward current generated by 5 -HT. Additional increase of cationic conductance may contribute to $I_{5-\mathrm{HT}}$. A concomitant slight reduction of $I_{h}$, however, might partly counteract these effects.

Distinct receptor subtypes mediate the depolarizing action of 5-HT in striatal cholinergic interneurons. In a further series of whole-cell patch-clamp experiments we investigated the effect of selective 5-HT2, 5-HT6, and 5-HT7 receptor activation on ion conductance (Figure 11). Bathapplication of the 5-HT2 receptor agonist DOI $(20 \mu \mathrm{M})$ induced an inward current in the recorded neurons $(57.4 \pm 11.3 \mathrm{pA}$; not shown; $n=4)$ and an increase in input resistance (107.4 $\pm 4.7 \%$ of control; $n=4 ; p<0.05)$. The net DOI-induced current, obtained by digital subtraction of the voltage ramps applied before and at the maximal effect of the agonist, showed a linear current-voltage relationship in the range between -120 and $-70 \mathrm{mV}$, with a mean reversal potential of $-79.4 \pm 2.4 \mathrm{mV}$ (Figure $11 \mathrm{~b} ; n=7$ ). These data suggest that closing of $\mathrm{K}^{+}$channels is involved in the 5-HT2 receptor-induced inward current. To selectively activate 5-HT6 receptor, $30 \mu \mathrm{M}$ 5-HT was applied after blockade of both 5-HT2C and 5-HT7 receptor with the selective antagonists RS 102221 and SB 269970 (3 $\mu \mathrm{M}$ each). 5-HT6 activation caused an increase in input resistance
$(108 \pm 1.7 \%$ of control; $n=8 ; p<0.01)$ and induced an inward current of $46.4 \pm 7.7 \mathrm{pA}$ (not shown). The digitallysubtracted current induced by 5 -HT in the presence of RS 102221 and SB 269970 showed a linear currentvoltage relationship, with a mean reversal potential of $-91.7 \pm 3.7 \mathrm{mV}$ (Figure 11c; $n=8$ ). These data are consistent with a major involvement of $\mathrm{K}^{+}$conductance reduction in the inward current induced by 5-HT6 receptor activation. Bath-application of $10 \mu \mathrm{M}$ 5-CT, the selective 5-HT7 receptor agonist, induced an inward current in the recorded neurons (87.9 $\pm 4.7 \mathrm{pA}$; not shown; $n=6)$. The absence of significant changes in input resistance $(97.8 \pm 3.1 \% ; n=6$; $p>0.05)$ and of a reversal potential for the net 5-CTinduced current in the voltage range examined (Figure 11d) suggests the simultaneous opening and closure of different channels. Interestingly, activation of either 5-HT2, 5-HT6 or 5-HT7 receptor induced a reduction of $I_{\mathrm{h}}$ (to $91.1 \pm 3.7 \%$, $90.9 \pm 4.9 \%$, and $94.3 \pm 3.4 \%$ of control, respectively), that did not reach statistical significance $(p>0.05)$.

\section{DISCUSSION}

Compelling evidence suggests that 5 -HT modulates cholinergic signalling in several brain areas (Cassel and Jeltsch, 1995; Bourson et al, 1998). Depending upon the specific 
region involved, this functional interaction may powerfully influence cognitive functions as well as motor activity. In the present work, evidence is provided for a 5-HT-mediated excitatory influence on cholinergic interneurons of the striatum. This effect occurs through the activation of multiple receptor subtypes, namely 5-HT2C, 5-HT6, and 5-HT7, resulting in an inward current/membrane depolarization response. According to the transduction pathways linked to the receptor subtypes involved in the 5-HTinduced effect, the response of striatal cholinergic interneurons was partially blocked by either PLC or adenylyl cyclase inhibitors. In support of the pharmacological study, the PCR analysis confirmed the presence of 5-HT2C, 5-HT6, and 5-HT7 receptors on cholinergic interneurons. Furthermore, an endogenous 5-HT effect was demonstrated. Blockade of either receptor subtype caused, per s̀̀, a reduction in the action potential frequency in spontaneously firing neurons. Moreover, the 5-HT reuptake blockers citalopram and fluvoxamine mimicked the excitatory action of exogenous 5-HT. The citalopram-induced excitation was reduced by each of the selective 5-HT2C, 5-HT6, and 5-HT7 antagonists. These observations support the hypothesis of an endogenous serotonergic tone modulating cholinergic function. Interestingly, constitutive activity of the 5-HT2C receptor has been shown to inhibit in vivo dopamine release in the rat striatum (De Deurwaerdere et al, 2004).

\section{5-HT-Dependent Membrane Depolarization/Inward Current}

A 5-HT-dependent membrane depolarization has been observed in a variety of neuronal subtypes in different brain regions, involving various ionic mechanisms (Chapin and Andrade, 2001; Chapin et al, 2002; Xiang et al, 2005; for a review, see Hoyer et al, 2002). This observation suggests an important role for 5-HT in modulating neuronal excitability in several brain areas. Our data show that 5-HT depolarizes the cell membrane and increases the firing rate of the recorded neurons.

In principle, a depolarization may be due to an increase in excitatory transmission. However, blocking synaptic transmission produced little effect on 5-HT-induced inward currents or membrane depolarization, suggesting that postsynaptic, not presynaptic, mechanisms are responsible for 5-HT-induced excitatory response. Thus, 5-HT-induced cell depolarization and increase in firing frequency might be caused by the inhibition of $\mathrm{K}^{+}$currents, or increase of a cationic conductance. Several lines of evidence argue for a closure of $\mathrm{K}^{+}$conductance by $5-\mathrm{HT}$ in striatal cholinergic interneurons. First, 5-HT application induced an increase in input resistance. Second, the estimated reversal potential of the 5-HT-induced current was close to the $\mathrm{K}^{+}$equilibrium potential and was shifted to less negative values by increasing the extracellular $\mathrm{K}^{+}$concentration. Third, the $\mathrm{K}^{+}$channel blocker $\mathrm{Ba}^{2+}$ significantly reduced the amplitude of the 5-HT-induced current.

Of note, 5-HT has already been reported to exert an excitatory effect by suppressing $\mathrm{K}^{+}$conductances in other striatal neuronal subtypes (Stefani et al, 1990), as well as in nucleus accumbens neurons, subthalamic nucleus neurons, and cortical pyramidal neurons (North and Uchimura, 1989;
Zhang, 2003; Xiang et al, 2005). In particular, in agreement with our data on striatal cholinergic interneurons, in other neuronal populations the excitatory responses to 5-HT2C receptor activation have been reported to be mediated by the closing of $\mathrm{K}^{+}$channels (Hsiao et al, 1997; Xiang et al, 2005).

Among $\mathrm{K}^{+}$channels, an involvement of both Kir and $K_{\text {leak }}$ has been reported in the 5-HT-induced excitation. A closure of $K_{\text {leak }}$ channels was shown to mediate the 5-HTinduced depolarization in dorsal vagal neurons (Hopwood and Trapp, 2005) and to be involved in the response of trigeminal and spinal cord motoneurons to 5-HT (Hsiao et al, 1997; Kjaerulff and Kiehn, 2001). In caudal raphe and nucleus accumbens and in motoneurons of the spinal cord, 5-HT has been reported to reduce Kir conductance (North and Uchimura, 1989; Bayliss et al, 1997; Kjaerulff and Kiehn, 2001). Interestingly, $I_{\mathrm{Kir}}$ is involved in the regulation of the spontaneous firing activity of striatal cholinergic interneurons by counteracting a prominent $\mathrm{HCN}$ conductance (Wilson, 2005). Furthermore, $K_{\text {leak }}$ conductance participate in the modulation of membrane potential in this neuronal population (Takeshita et al, 1996). Our data suggest a role of Kir channels in mediating $I_{5-\mathrm{HT}}$. Indeed, the comparison between the 5-HT-sensitive current recorded after HCN channel blockade by either ZD 7288 or $\mathrm{Cs}^{+}$, suggests that $5-\mathrm{HT}$ acts on Kir channels. The residual $\mathrm{Cs}^{+}{ }_{-}$ insensitive $\mathrm{K}^{+}$conductance might be carried by $K_{\text {leak }}$ channels. The identification of the additional cationic conductance activated by 5-HT needs further investigation (Hsiao et al, 1997).

5-HT has been reported to exert a modulatory effect on $I_{\mathrm{h}}$ in different neuronal types. Both facilitatory and inhibitory actions have been reported (McCormick and Pape, 1990; Li et al, 1993; Zhang, 2003). 5-HT7 receptor was shown to facilitate $I_{\mathrm{h}}$ through a cAMP-mediated mechanism (Chapin and Andrade, 2001), whereas in ventral tegmental area dopamine neurons, 5-HT2 receptor activation has been reported to reduce $I_{\mathrm{h}}$ through a PKC-dependent mechanism (Liu et al, 2003). In striatal cholinergic interneurons, we observed an inhibitory effect of 5-HT on $I_{\mathrm{h}}$. Interestingly, activation of either 5-HT2, 5-HT6 or 5-HT7 receptor was involved in the 5-HT-mediated reduction of $I_{\mathrm{h}}$. In cholinergic interneurons, the excitatory effect of 5-HT, mediated both by a closing of $\mathrm{K}^{+}$-selective channels and an increase of cation conductance, might be counteracted by the 5-HT-induced inhibitory action on $I_{\mathrm{h}}$, in a complex interplay as observed in the regulation of spontaneous firing activity (Wilson, 2005).

\section{Pharmacological Characterization of the Receptor Subtype}

Currently, 14 5-HT receptors have been identified and grouped into seven classes (5-HT1 to 5-HT7). Among 5-HT receptors, only 5 -HT3 is a ligand-gated ion channel, whereas the other receptors belong to the G-proteincoupled receptor (GPCR) superfamily. The striatum expresses a variety of 5-HT receptors: 5-HT1B and 5-HT1E (Bruinvels et al, 1994), 5-HT2A and 5-HT2C (Ward and Dorsa, 1996), 5-HT3 (Blandina et al, 1989; Rondé and Nichols, 1998), 5-HT4 (Jakeman et al, 1994; Waeber et al, 1994; Gerald et al, 1995; Patel et al, 1995), and 5-HT6 
(Ruat et al, 1993; Ward and Dorsa, 1996; Gerard et al, 1997). The striatal expression of 5-HT7 is controversial (Vizuete et al, 1997; Martin-Cora and Pazos, 2004). The diversity of receptor subtypes matches the complexity of effects exerted by $5-\mathrm{HT}$ on its target cells. In the basal ganglia, 5-HT receptors belonging to the 5 -HT2C or 5-HT4 class have been reported to mediate the 5-HT-induced excitation of subthalamic nucleus and substantia nigra pars reticulata neurons (Rick et al, 1995; Xiang et al, 2005). Several studies have demonstrated, within the striatum, a high level of expression of 5-HT2 receptors (Ward and Dorsa, 1996) and the highest levels of 5-HT6 mRNA (Ruat et al, 1993; Branchek and Blackburn, 2000). Interestingly, a doublelabel in situ hybridization study reported that 5-HT2A, 5HT2C, and 5-HT6 receptors colocalize within the striatum either in enkephalin- or in substance P-containing spiny neurons (Ward and Dorsa, 1996). Our electrophysiological and PCR data demonstrate the expression of 5-HT2C, 5-HT6, and 5-HT7 receptors in striatal cholinergic interneurons, where each of them contributes to the depolarization/inward current induced by $5-\mathrm{HT}$. These findings suggest a regional specificity in the pattern of 5-HT receptor subtypes expression.

\section{Transduction Pathways}

With the exception of the ionotropic 5-HT3 receptor, the remaining classes of 5-HT receptors are coupled to $\mathrm{G}_{\mathrm{i} / \mathrm{o}}, \mathrm{G}_{\mathrm{q}}$ or $\mathrm{G}_{\mathrm{s}}$ proteins. In particular, 5-HT6 and 5-HT7 receptors have been reported to be positively coupled to adenylyl cyclase activation through $\mathrm{G}_{\mathrm{s}}$ protein, whereas the 5-HT2 class of serotonergic receptors is coupled to $G_{q}$ protein and PLC activation (Sebben et al, 1994). Accordingly, our pharmacological analysis shows that blockade of either adenylyl cyclase or PLC activity reduces the 5-HT-induced response in cholinergic interneurons. The excitatory action of 5-HT seems to be independent of protein kinase activity, as previously reported in other neuronal types (Larkman and Kelly, 1997; Chapin et al, 2002; Chapin and Andrade, 2001).

Thus, multiple pathways may be available for the modulation of $\mathrm{HCN}$ and $\mathrm{K}^{+}$conductance by 5-HT in striatal cholinergic interneurons. Indeed, both $\mathrm{HCN}$ and $K_{\text {leak }}$ channels are modulated by cytosolic cAMP levels, making them potential mediators of 5-HT6 and 5-HT7 receptor action (Pape, 1996; Siegelbaum et al, 1982). Moreover, 5-HT2 receptors have been reported to reduce $I_{\mathrm{h}}$ through a PKC-dependent mechanism (Liu et al, 2003), and PLC has been shown to mediate the suppression of $I_{\mathrm{Kir}}$ in nucleus basalis neurons (Takano et al, 1996).

\section{Functional Implication}

The serotonin reuptake inhibitors are widely used for the treatment of depression. However, this class of drugs has been reported to produce extrapyramidal effects, particularly akathisia, dystonia, and parkinsonism (Leo, 1996; Pina Latorre et al, 2001). The mechanisms underlying such adverse effects are unknown although they are likely linked to a serotonergic effect within the basal ganglia structures.

Striatal cholinergic transmission is a key element not only to the control of voluntary movement, but also to the clinical manifestations of movement disorders such as Parkinson's disease (Kaneko et al, 2000; Raz et al, 2001). Notably, in vivo recordings from TANs in primates have shown that MPTP treatment induces an oscillatory electrical activity, in a frequency range that overlaps the range of the tremor frequencies (Raz et al, 2001). Thus, it might be postulated that the excitatory effect produced by $5-\mathrm{HT}$ on cholinergic interneurons might represent, at least to some extent, a plausible determinant for the extrapyramidal side effects induced by 5 -HT reuptake inhibitors, by promoting intrastriatal release of acetylcholine. This is in agreement with the evidence that 5-HT indeed stimulates acetylcholine release in the striatum (Bianchi et al, 1989). Hence, modulating striatal cholinergic signaling might prove useful to the pharmacological treatment of these movement disorders.

\section{ACKNOWLEDGEMENTS}

We thank Professor Nicola Mercuri for critical reading of the manuscript; Mr Massimo Tolu and Mr Franco Lavaroni for excellent technical assistance. This work was supported by grants from Dystonia Medical Research Foundation, Ministero Istruzione Università Ricerca (FIRB 2001), and Progetto Finalizzato Ministero Salute, to AP, GB, and PB.

\section{REFERENCES}

Albin RL, Cross D, Cornblath WT, Wald JA, Wernette K, Frey KA et al (2003). Diminished striatal $\left[{ }^{123} \mathrm{I}\right]$ iodobenzovesamicol binding in idiopathic cervical dystonia. Ann Neurol 53: 528-532.

Aosaki T, Kiuchi K, Kawaguchi Y (1998). Dopamine D1-like receptor activation excites rat striatal large aspiny neurons in vitro. J Neurosci 18: 5180-5190.

Bayliss DA, Li YW, Talley EM (1997). Effects of serotonin on caudal raphe neurons: inhibition of $\mathrm{N}$ - and $\mathrm{P} / \mathrm{Q}$-type calcium channels and the afterhyperpolarization. J Neurophysiol 77: 1362-1374.

Bennett BD, Callaway JC, Wilson CJ (2000). Intrinsic membrane properties underlying spontaneous tonic firing in neostriatal cholinergic interneurons. J Neurosci 20: 8493-8503.

Bennett BD, Wilson CJ (1999). Spontaneous activity of neostriatal cholinergic interneurons in vitro. J Neurosci 19: 5586-5596.

Bianchi C, Siniscalchi A, Beani L (1989). Effect of 5-hydroxytryptamine on $[3 \mathrm{H}]$-acetylcholine release from guinea-pig striatal slices. Br J Pharmacol 97: 213-221.

Blandina P, Goldfarb J, Craddock-Royal B, Green JP (1989). Release of endogenous dopamine by stimulation of 5-hydroxytryptamine 3 receptors in rat striatum. J Pharmacol Exp Ther 251: 803-809.

Bonsi P, Cuomo D, De Persis C, Centonze D, Bernardi G, Calabresi $\mathrm{P}$ et al (2005). Modulatory action of metabotropic glutamate receptor (mGluR) 5 on mGluR1 function in striatal cholinergic interneurons. Neuropharmacology 49: 104-113.

Bonsi P, De Persis C, Calabresi P, Bernardi G, Pisani A (2004). Coordinate high-frequency pattern of stimulation and calcium levels control the induction of LTP in striatal cholinergic interneurons. Learn Mem 11: 755-760.

Bourson A, Boess FG, Bos M, Sleight AJ (1998). Involvement of 5-HT6 receptors in nigro-striatal function in rodents. $\mathrm{Br} J$ Pharmacol 125: 1562-1566.

Branchek TA, Blackburn TP (2000). 5-HT6 receptors as emerging targets for drug discovery. Annu Rev Toxicol 40: 319-334.

Bruinvels AT, Landwehrmeyer B, Gustafson EL, Durkin MM, Mengod G, Branchek TA et al (1994). Localization of 5-HT1B, 
5-HT1Dalpha, 5-HT1E and 5-HT1F receptor messenger RNA in rodent and primate brain. Neuropharm 33: 367-386.

Caley CF (1997). Extrapyramidal reactions and the selective serotonin-reuptake inhibitors. Ann Pharmacother 31: 1481-1489.

Cassel J-C, Jeltsch H (1995). Serotonergic modulation of cholinergic function in the central nervous system: cognitive implications. Neurosci 69: 1-41.

Chapin EM, Andrade R (2001). A 5-HT(7) receptor-mediated depolarization in the anterodorsal thalamus. II. Involvement of the hyperpolarization-activated current $I(\mathrm{~h})$. J Pharmacol Exp Ther 297: 403-409.

Chapin EM, Haj-Dahmane S, Torres G, Andrade R (2002). The 5 -HT(4) receptor-induced depolarization in rat hippocampal neurons is mediated by cAMP but is independent of $I(\mathrm{~h})$. Neurosci Lett 324: 1-4.

De Deurwaerdere P, Navailles S, Berg KA, Clarke WP, Spampinato $\mathrm{U}$ (2004). Constitutive activity of the serotonin2C receptor inhibits in vivo dopamine release in the rat striatum and nucleus accumbens. J Neurosci 24: 3235-3241.

Gerald C, Adham N, Kao HT, Olsen MA, Laz TM, Schechter LE et al (1995). The 5-HT4 receptor: molecular cloning and pharmacological characterization of two splice variants. $E M B O$ J 14: 2806-2815.

Gerard C, Martres MP, Lefevre K, Miquel MC, Verge D, Lanfumey $\mathrm{L}$ et al (1997). Immuno-localization of serotonin 5-HT6 receptor-like material in the rat central nervous system. Brain Res 746: 207-219.

Halliday GM, Blumbergs PC, Cotton RG, Blessing WW, Geffen LB (1990). Loss of brainstem serotonin- and substance P-containing neurons in Parkinson's disease. Brain Res 510: 104-107.

Hopwood SE, Trapp S (2005). TASK-like K+ channels mediate effects of 5-HT and extracellular $\mathrm{pH}$ in rat dorsal vagal neurones in vitro. J Physiol 568: 145-154.

Hoyer D, Hannon JP, Martin GR (2002). Molecular, pharmacological and functional diversity of 5-HT receptors. Pharmacol Biochem Behav 71: 533-554.

Hsiao CF, Trueblood PR, Levine MS, Chandler SH (1997). Multiple effects of serotonin on membrane properties of trigeminal motoneurons in vitro. J Neurophysiol 77: 2910-2924.

Izzo PN, Bolam JP (1988). Cholinergic synaptic input to different parts of spiny striatonigral neurons in the rat. J Comp Neurol 269: 219-234.

Jakeman LB, To ZP, Eglen RM, Wong EH, Bonhaus DW (1994). Quantitative autoradiography of 5-HT4 receptors in brains of three species using two structurally distinct radioligands, [3H]GR113808 and [3H]BIMU-1. Neuropharm 33: 1027-1038.

Jiang ZG, North RA (1991). Membrane properties and synaptic responses of rat striatal neurones in vitro. J Physiol 443: 533-553.

Kaneko S, Hikida T, Watanabe D, Ichinose H, Nagatsu T, Kreitman $\mathrm{RJ}$ et al (2000). Synaptic integration mediated by striatal cholinergic interneurons in basal ganglia function. Science 289: 633-637.

Kawaguchi Y (1993). Physiological, morphological and histochemical characterization of three classes of interneurons in rat neostriatum. J Neurosci 13: 4908-4923.

Kjaerulff O, Kiehn O (2001). 5-HT modulation of multiple inward rectifiers in motoneurons in intact preparations of the neonatal rat spinal cord. J Neurophysiol 85: 580-593.

Larkman PM, Kelly JS (1997). Modulation of IH by 5-HT in neonatal rat motoneurones in vitro: mediation through a phosphorylation independent action of cAMP. Neuropharmacology 36: 721-733.

Lavoie B, Parent A (1990). Immunohistochemical study of the serotoninergic innervation of the basal ganglia in the squirrel monkey. J Comp Neurol 299: 1-16.

Lehmann J, Langer SZ (1983). The striatal cholinergic interneuron: synaptic target of dopaminergic terminals? Neuroscience 10: $1105-1120$.
Leo RJ (1996). Movement disorders associated with the serotonin selective reuptake inhibitors. J Clin Psychiatry 57: 449-454.

Li SJ, Wang Y, Strahlendorf HK, Strahlendorf JC (1993). Serotonin alters an inwardly rectifying current (Ih) in rat cerebellar Purkinje cells under voltage clamp. Brain Res 617: 87-95.

Liu Z, Bunney EB, Appel SB, Brodie MS (2003). Serotonin reduces the hyperpolarization-activated current (Ih) in ventral tegmental area dopamine neurons: involvement of 5-HT2 receptors and protein kinase C. J Neurophysiol 90: 3201-3212.

Martin-Cora FJ, Pazos A (2004). Autoradiographic distribution of 5-HT7 receptors in the human brain using [3H]mesulergine: comparison to other mammalian species. Br J Pharmacol 141: 92-104.

Maurice N, Mercer J, Chan CS, Hernandez-Lopez S, Held J, Tkatch $\mathrm{T}$ et al (2004). D2 dopamine receptor-mediated modulation of voltage-dependent $\mathrm{Na}+$ channels reduces autonomous activity in striatal cholinergic interneurons. J Neurosci 24: 10289-10301.

McCormick DA, Pape HC (1990). Noradrenergic and serotonergic modulation of a hyperpolarization-activated cation current in thalamic relay neurones. $J$ Physiol 431: 319-342.

North RA, Uchimura N (1989). 5-Hydroxytryptamine acts at 5HT2 receptors to decrease potassium conductance in rat nucleus accumbens neurones. J Physiol 417: 1-12.

Pape HC (1996). Queer current and pacemaker: hyperpolarizationactivated cation current in neurons. Annu Rev Physiol 58: 299-327.

Park MR, Gonzales-Vegas JA, Kitai ST (1982). Serotonergic excitation from dorsal raphe stimulation recorded intracellularly from rat caudate-putamen. Brain Res 243: 49-58.

Patel S, Roberts J, Moorman J, Reavill C (1995). Localization of serotonin-4 receptors in the striatonigral pathway in rat brain. Neurosci 69: 1159-1167.

Pina Latorre MA, Modrego PJ, Rodilla F, Catalan C, Calvo M (2001). Parkinsonism and Parkinson's disease associated with long-term administration of sertraline. J Clin Pharm Ther 26: 111-112.

Pisani A, Bonsi P, Centonze D, Calabresi P, Bernardi G (2000). Activation of D2-like dopamine receptors reduces synaptic inputs to striatal cholinergic interneurons. J Neurosci 20: RC69.

Pisani A, Bonsi P, Centonze D, Martorana A, Fusco F, Sancesario G et al (2003). Activation of $\beta 1$-adrenoceptors excites striatal cholinergic interneurons through a cAMP-dependent, protein kinase-independent pathway. J Neurosci 23: 5272-5282.

Raz A, Frechter-Mazar V, Feingold A, Abeles M, Vaadia E, Bergman H (2001). Activity of pallidal and striatal tonically active neurons is correlated in mptp-treated monkeys but not in normal monkeys. J Neurosci 21: RC128.

Rick CE, Stanford IM, Lacey MG (1995). Excitation of rat substantia nigra pars reticulata neurons by 5 -hydroxytryptamine in vitro: evidence for a direct action mediated by 5-hydroxytryptamine2C receptors. Neurosci 69: 903-913.

Rondé P, Nichols RA (1998). High calcium permeability of serotonin 5-HT3 receptors on presynaptic nerve terminals from rat striatum. J Neurochem 70: 1094-1103.

Ruat M, Traiffort E, Arrang JM, Tardivel-Lacombe J, Diaz J, Leurs $\mathrm{R}$ et al (1993). A novel rat serotonin (5-HT6) receptor: molecular cloning, localization and stimulation of cAMP accumulation. Biochem Biophys Res Commun 193: 268-276.

Sandyk R, Fisher H (1988). Serotonin in involuntary movement disorders. Int J Neurosci 42: 185-208.

Saulle E, Gubellini P, Picconi B, Centonze D, Tropepi D, Pisani A et al (2004). Neuronal vulnerability following inhibition of mitochondrial complex II: a possible ionic mechanism for Huntington's disease. Mol Cell Neurosci 25: 9-20.

Sebben M, Ansanay H, Bockaert J, Dumuis A (1994). 5-HT6 receptors positively coupled to adenylyl cyclase in striatal neurones in culture. Neuroreport 18: 2553-2557. 
Siegelbaum SA, Camardo JS, Kandel ER (1982). Serotonin and cyclic AMP close single $\mathrm{K}^{+}$channels in Aplysia sensory neurons. Nature 299: 413-417.

Stefani A, Surmeier DJ, Kitai ST (1990). Serotonin enhances excitability in neostriatal neurons by reducing voltage-dependent potassium currents. Brain Res 529: 354-357.

Suzuki T, Miura M, Nishimura K, Aosaki T (2001). Dopaminedependent synaptic plasticity in the striatal cholinergic interneurons. J Neurosci 21: 6492-6501.

Takano K, Yasufuku-Takano J, Kozasa T, Singer WD, Nakajima S, Nakajima Y (1996). Gq/11 and PLC-beta 1 mediate the substance $\mathrm{P}$-induced inhibition of an inward rectifier $\mathrm{K}+$ channel in brain neurons. J Neurophysiol 76: 2131-2136.

Takeshita Y, Harata N, Akaike N (1996). Suppression of K+ conductance by metabotropic glutamate receptor in acutely dissociated large cholinergic neurons of rat caudate putamen. J Neurophysiol 76: 1545-1558.

Tkatch T, Baranauskas G, Surmeier DJ (1998). Basal forebrain neurons adjacent to the globus pallidus co-express GABAergic and cholinergic marker mRNAs. Neuroreport 9: 1935-1939.

Vizuete ML, Venero JL, Traiffort E, Vargas C, Machado A, Cano J (1997). Expression of 5-HT7 receptor mRNA in rat brain during postnatal development. Neurocsi Lett 227: 53-56.

Waeber C, Sebben M, Nieoullon A, Bockaert J, Dumuis A (1994). Regional distribution and ontogeny of 5-HT4 binding sites in rodent brain. Neuropharm 33: 527-541.
Ward RP, Dorsa DM (1996). Colocalization of serotonin receptor subtypes 5-HT2A, 5-HT2C, and 5-HT6 with neuropeptides in rat striatum. J Comp Neurol 370: 405-414.

Warren NM, Piggott MA, Perry EK, Burn DJ (2005). Cholinergic systems in progressive supranuclear palsy. Brain 128: 239-249.

Wilson CJ (2005). The mechanisms of intrinsic amplification of hyperpolarizations and spontaneous bursting in striatal cholinergic interneurons. Neuron 45: 575-585.

Xiang Z, Wang L, Kitai ST (2005). Modulation of spontaneous firing in rat subthalamic neurons by 5 -HT reeptor subtypes. J Neurophysiol 93: 1145-1157.

Yakel JL, Trussell LO, Jackson MB (1988). Three serotonin responses in cultured mouse hippocampal and striatal neurons. Neuroscience 8: 1273-1285.

Yan Z, Surmeier DJ (1997). D5 dopamine receptors enhance $\mathrm{Zn} 2+$-sensitive GABA(A) currents in striatal cholinergic interneurons through a PKA/PP1 cascade. Neuron 19: 11151126.

Yan Z, Song WJ, Surmeier J (1997). D2 dopamine receptors reduce $\mathrm{N}$-type Ca2+ currents in rat neostriatal cholinergic interneurons through a membrane-delimited, protein-kinase-C-insensitive pathway. J Neurophysiol 77: 1003-1015.

Zhang ZW (2003). Serotonin induces tonic firing in layer V pyramidal neurons of rat prefrontal cortex during postnatal development. J Neurosci 23: 3373-3384. 